\section{Tomasz Tułodziecki}

Uniwersytet Mikołaja Kopernika w Toruniu thomast@umk.pl

ORCID: 0000-0002-7650-8543

DOI: http://dx.doi.org/10.12775/BPTh.2018.005
Biblica

et

Patristica

Thoruniensia

11 (2018) 1: 101-127

ISSN (print) 1689-5150

ISSN (online) 2450-7059

\title{
„Nasza ojczyzna jest w niebie”. Wykład św. Pawła na temat rzeczy ostatecznych w Liście do Filipian (Flp 3,1-4,1)
}

\section{"Our citizenship is in heaven." St Paul's discourse on the final things in Philippians. (Phi 3:1-4:1)}

Streszczenie: Podobnie jak w Listach do Rzymian i do Galatów podstawą doktryny św. Pawła w Liście do Filipian jest usprawiedliwienie z wiary w Chrystusa (Flp 3,9). Prawdę tę Apostoł wypowiada podczas konfrontacji ze swoimi przeciwnikami, powołując się jednocześnie na fakty towarzyszące jego powołaniu na urząd Apostoła. Paweł dzieli

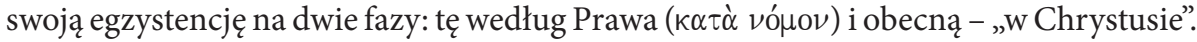
Jego postawa i doświadczenie Boga ma jednocześnie wartość paradygmatu i przykładu. Podobnie jak Apostoł Narodów zerwał z przepisami Prawa, tak również dla Filipian, których wzywa do naśladowania go na drodze Ewangelii, Tora i jej zasady powinny stać się anachronizmem $(3,17)$. Droga ewangeliczna według św. Pawła rozciąga się pomiędzy tym „co teraz”, nazywanym przez Pawła „udziałem w cierpieniach Chrystusa”, a nadzieją zmartwychwstania, które jest zwieńczeniem chrześcijańskiego powołania. Na tych dwóch motywach teologicznych i literackich św. Paweł oparł całą treść swojego przesłania zawartą w Flp 3,1-4,1. Można ją wyrazić za pomocą parafrazy słów samego Apostoła Narodów: tak Filipianie, jak i rodzący się Kościół winni oczekiwać Pana (Kupíos), Jezusa Chrystusa jako Zbawiciela, który przekształci naszą poniżoną ludzką naturę na podobieństwo swojego uwielbionego ciała $(3,21)$. W tej prawdzie zawiera się najbardziej zwięzłe przesłanie Pawłowej eschatologii płynące z kart Listu do Filipian.

Summary. As in the Letters to the Romans and the Galatians, the foundation of St. Paul's doctrine in the Letter to the Philippians is a righteousness that comes through faith in Christ (Phil 3:9). The Apostle proclaims this truth during a confrontation with his opponents referring at the same time to the fact which accompanied his call to dis-

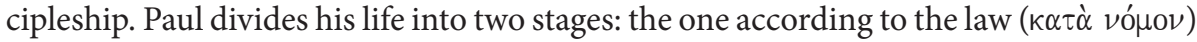
and the present one "in Christ". His attitude and experience of God have the value of paradigm and example. As the Apostle of the Nations broke with the precepts of the Law he encourages the Philippians to follow his example on the way to the Gospel. The Torah and its rules should be an anachronism (3:17). According to St. Paul, the way 
of the Gospel stretches between what is now and what Paul calls the participation in Christ's sufferings and the hope of resurrection which is the culmination of a Christian vocation. St. Paul bases his whole message in Phil 3:1-4:1 on these two theological and literary themes. It might be expressed using the paraphrase of the Apostle's words that both the Philippians and the growing Church should await the Lord (Kupios), Jesus Christ as the Saviour who will transform the body of our humiliation so that it may be conformed to the body of his glory (Phil 3:21). This truth expresses the most succinct message of Paul's eschatology coming from the pages of the Letter to the Philippians.

Słowa klucze: usprawiedliwienie; prześladowanie; eschatologia; zmartwychwstawanie Filipianie; wspólnota; nadzieja; wieczność.

Keywords: justification; persecution; eschatology; resurrection; Filippians; community; hope; eternity.

$P$ ainteresowanie św. Pawła tematyką eschatologiczną przenika większość pism Apostoła Narodów. Jest to jeden z najbardziej ulubionych Pawłowych tematów. Faktem, który stoi u podstaw wszelkich dyskusji i chrześcijańskiej doktryny eschatologicznej, jest zmartwychwstanie Chrystusa. Streszcza on tę prawdę praktycznie w jednym podstawowym stwierdzeniu: „Jeśli nie ma zmartwychwstania, to i Chrystus nie zmartwychwstał. A jeśli Chrystus nie zmartwychwstał, daremne jest nasze nauczanie, próżna jest także wasza wiara” (1 Kor 15,13-14). Dla św. Pawła jest droga, na której Chrystus Pan odzyskuje swą potęgę i majestat, odebrane mu przez mękę i śmierć krzyżową. Poprzez zmartwychwstanie Jezus Chrystus otrzymuje ponownie synowski autorytet, zasiadając po prawicy Boga Ojca w niebie. Z jednej strony zmartwychwstanie Chrystusa jest dla św. Pawła aktem eschatologicznym, z drugiej zaś - Apostoł podkreśla zawsze jego ziemski i materialny wymiar. Zmartwychwstanie w pismach Pawłowych to zawsze akt historyczny, w którym Chrystus ukazuje także nową formę cielesnej egzystencji. Szczególnie dobitnie podkreśla te prawdy wspomniany już wywód Apostoła w 1 Kor 15. Ukazując dyskusję Apostoła na temat natury ziemskich i niebieskich ciał, w którym podkreśla on fizyczny wymiar duchowego ciała „drugiego Adama”.

Św. Paweł był dzieckiem swojego czasu. Dzielił on historię na dwa okresy:

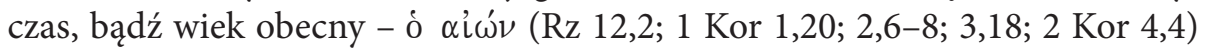
i wiek przyszły. Termin „wiek przyszły” nie występuje bezpośrednio w żadnym z pism św. Pawła, jednakże zna on pojęcia „pełni czasów” (1 Kor 10,11), „tego, co dawne” i „tego, co nowe” (1 Kor 10,11). Wskazując jednocześnie, że wiek

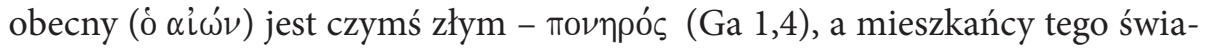
ta to „naród przewrotny i zakłamany” (Flp 2,15). Nadchodzącą epokę escha- 


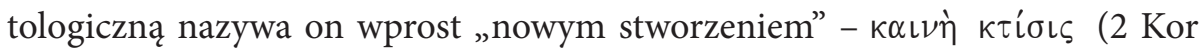
5,17; Ga 6,15). Wiąże się ono z ponownym przyjściem i objawieniem się Syna Człowieczego. Szczególnie wyrazistym tekstem podkreślającym ów czasowy dualizm i kontrast pomiędzy „złym teraz” i „eschatologiczną nowością” jest List do Filipian. Tematem zasadniczym tego dzieła jest przede wszystkim kô เ $\omega \nu i ́ \alpha$, czyli „wspólnota”, „uczestnictwo” bądź „udział”. Ta idea pojawia się już w tzw. exordium Listu do Filipian (1,5.7): zarówno św. Paweł, jak i mieszkańcy Filippi przeżywają te same utrapienia i prześladowanie z powodu Ewangelii Jezusa Chrystusa ${ }^{1}$. Dla Apostoła Narodów oznacza to udział w cierpieniach krzyża Jezusa Chrystusa i nadzieję na dostąpienie chwały zmartwychwstania. Szczególnym wyrazem tego przeświadczenia jest tekst $\mathrm{w}$ formie hymnu zawarty w Flp 2,6-11. Eschatologiczny wymiar Listu do Filipian wyraża się jednak przede wszystkim w napięciu, które najlepiej wyrażają dwa terminy: z jednej strony tzw. „już", co odnosi się do ziemskiego mozołu, który naznaczony jest cierpieniem dla imienia Jezusa, z drugiej zaś tzw. „jeszcze nie”, wskazującego na niebiańską przyszłość obiecaną tym, którzy wytrwają w przeciwnościach znoszonych dla Ewangelii. Jednym słowem adresaci Listu do Filipian żyją już dla Chrystusa tu i teraz, lecz w taki sposób, aby wszystko w ich życiu było zorientowane na przyszły eschaton. Należą już do Chrystusa, ale nie doświadczyli jeszcze pełni zbawienia ${ }^{2}$.

To zbawienie w Liście do Filipian ma według św. Pawła aspekt materialny, chodzi o wydarzenie na poziomie fizycznym, w którym ciało ludzkie ulegnie transformacji i otrzyma nową formę, jeśli dostąpi udziału w chwale Chrystusa:

Nasza bowiem ojczyzna jest w niebie. Stamtąd też jako Zbawcy wyczekujemy Pana naszego Jezusa Chrystusa, który przekształci nasze ciało poniżone, na podobne do swego chwalebnego ciała, tą potęgą, jaką może On także wszystko, co jest, sobie podporządkować. $(3,20-21)$

Orientacja eschatologiczna Pawła Apostoła nie ogranicza się jednak tylko ku przyszłości. Punktem wyjścia dla niej jest właściwa postawa etyczna. Dla św. Pawła poznanie Chrystusa wymaga moralności godnej samego Pana, która swoje wypełnienie znajdzie kiedyś w chwale Pana. Warto zatem prześledzić drogę wymagań stawianych przez Apostoła Narodów chrześcijanom w Filippi w trosce o ich eschatologiczną przyszłość, tym bardziej że etyka i moralność

1 Zob. M. Theobald, Der Philipperbrief, s. 380.

2 Zob. F. Schnider, W. Stenger, Studien zum neutestamentlichen Briefformular, s. 92$-93.98-99$. 
prowadzące do zbawienia, proponowane mieszkańcom umiłowanej gminy św. Pawła ${ }^{3}$, nic nie straciły ze swojej aktualności.

\section{Kościół w Filippi i okoliczności napisania listu}

Filippi było jednym z najważniejszych miast starożytnej Macedonii. Założono je z woli króla Filipa II w latach 358-357 przed Chrystusem, który nadał mu także swoje imię. W drugim wieku przed Chrystusem miasto Filippi zostało zdobyte przez Rzymian. Spowodowało to, podobnie jak w leżących niedaleko Tesalonikach, jego szybki rozwój i wzrost znaczenia. Szczególny rozgłos Filippi zawdzięcza bitwie, która rozegrała się nieopodal tego miasta w roku 42 przed Chrystusem, w której Marek Antoniusz i Oktawian August pokonali zjednoczone siły republikańskie pod wodzą Brutusa i Kasjusza. Święty Paweł odwiedził Filippi prawdopodobnie ok roku 50 po Chrystusie. Było to pierwsze europejskie miasto na jego misjonarskim szlaku, o czym donoszą Dzieje Apostolskie 16,11-40.

Głównym powodem napisania Listu do Filipian było pragnienie wyrażenia wdzięczności mieszkańcom Filippi za dar materialny przekazany od nich Apostołowi za pośrednictwem Epafrodyta. On to przekazał także św. Pawłowi informacje o prześladowaniu chrześcijan w Filippi cierpiących ze względu na przyjętą Ewangelię Chrystusa. Sam Epafrodyt uzdrowiony z ciężkiej choroby postanowił wrócić do Filippi, skąd pochodził i gdzie był jego dom. Jego świadectwo o sytuacji Filipian jest jeszcze bardziej wiarygodne. Św. Paweł, mimo trudnych więziennych warunków, z wielką radością i siłą ducha, nakłania adresatów swojego pisma do zachowania wytrwałości i jedności z pozostałymi gminami (Flp 1,27-30). Według tradycji biblijnej, św. Paweł napisał List do Filipian w rzymskim więzieniu krótko przed swoją śmiercią około 62-63 roku przed Chrystusem. Wśród egzegetów trwa jednak stała dyskusja nad precyzyjną datacją tego listu. Druga rozpowszechniona propozycja datuje List do Filipian na lata 56-57 po Chrystusie, podczas trzeciej podróży misyjnej św. Pawła Aposto$\mathrm{la}^{4}$.

3 Zob. J. Wilk, Postawa świętej obojętności Apostoła Pawła na podstawie Listu do Filipian 4,11-13, s. 467.

4 Zob. G. D. Fee, Paul's Letter to the Phillippians, s. 1. 


\section{Kontekst literacki Flp 3,1-4,1}

Aby dokonać analizy intersującej nas perykopy Flp 3,1-4,1, w której św. Paweł zawarł swoje przesłanie eschatologiczne w Liście do Filipian, należy ustalić najpierw szczegółową strukturę tego dzieła i prześledzić proces argumentacji autora listu. Tylko spojrzenie na całość kompozycji Flp pozwoli na wytyczenie granic intersującego nas tekstu. Metoda retoryczna wydaje się tu najlepszym narzędziem literackim dla zrozumienia kontekstu poszczególnych tekstów Pawłowych.

Opierając się na analizach współczesnych komentatorów, strukturę retoryczną Listu do Filipian wyraża następujący schemat:

I. Exordium 1,1-11
A. Praescriptio 1,1-2
B. Modlitwa dziękczynna 1,3-11

II. Narratio $1,2-26$

A. Teraźniejszość: przepowiadanie Ewangelii 1,12-18a

B. Przyszłość: dla chwały Chrystusa i dla dobra Filipian 1,18b-26

III. Propositio 1,27-30

Apel o wytrwałość i zgodę

IV. Probatio 2,1-4,1

A. Postępowanie Filipian 2,1-18

B. Postępowanie Tymoteusza 2,19-24

C. Postępowanie Epafrodyta 2,25-30

D. Postępowanie Filipian i św. Pawła

V. Exhortatio 4,2-9

VI. Peroratio $4,10-23^{5}$

5 Proponowana struktura retoryczna Listu do Filipian opiera się na opracowaniach: D.F. Watsona, A Rhetorical Analisis of Philippians and Its Implications for the Unity Question, s. 61-77 oraz L.G. Bloomquista, The Function of Suffering in Philippians, s. 84-94. Oczywiście proponowana struktura Listu do Filipian nie jest jedyną propozycją podziału tego dzieła. Dzisiaj bardzo popularną koncepcją podziału jest teoria o kompozycji składającej się z dwóch listów ujętych przez redaktorów w jedną całość. Według tej hipotezy List do Filipian A tworzą fragmenty: 1,1-3,1a; 4,2-7 i 4,10-23, List do Filipian B tworzą teksty: 3,1b-4,1 oraz 4,8-9. Szerszą dyskusję na temat podwójnego podziału Flp podaje L. Bormann, Philippi, Stadt und Christengemeinde zur Zeit des Paulus, s. 110. 115; J. Gnilka, Der Philipperbrief, s. 6. 
Interesujący nas tekst, będący wywodem eschatologicznym św. Pawła w Liście do Filipian 3,1-4,1, stanowi czwartą część w probatio. W tym fragmencie Apostoł kontynuuje swoje wyjaśnienia kierowane do chrześcijan w Filippi: $\tau \dot{\alpha}$ $\pi \epsilon \rho \grave{u} u \omega \hat{\nu} \nu$, (propositio 1,27). Obecność zaimka osobowego w drugiej osobie liczby mnogiej w Flp 3,1 (ì $\mu \hat{\imath} \nu$ ) nawiązuje do podstawowej tezy postawionej na

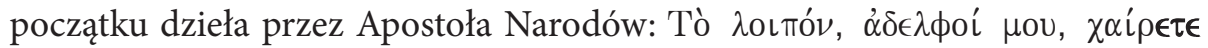

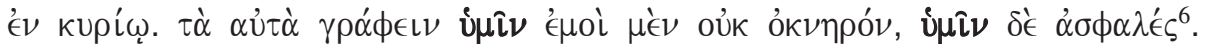
Badając kontekst perykopy 3,1-4,1 należy zapytać o jej granice. Z tekstu Flp wynika jasno, że wiersz 2,30 kończy dyskusję na temat losów Epafrodyta („... bo dla sprawy Chrystusa bliski był śmierci, naraziwszy życie swoje..."). Nato-

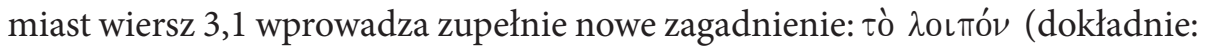
„z resztą", „poza tym”, użyte w formie biernika l. poj. rodz. nijakiego) wprowadza temat zawiązany z samą konkluzją listu, tzn. postawą Filipian wobec dotykających ich prześladowań oraz koniecznością naśladowania Chrystusa. Tym

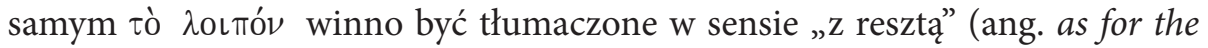
rest) podobnie jak w innych pismach św. Pawła: 1 Tes 4,1 i 2 Tes 3,1. Błędne jest natomiast tłumaczenie tego wyrażenia jako konkluzji w sensie "na koniec” czy „ostatecznie” bądź „w końcu”. Interesujący nas fragment kończy się w wierszu 4,1, który otwiera termin $̋ \sigma \tau \epsilon$. Św. Paweł użył spójnika, który wyjaśnia

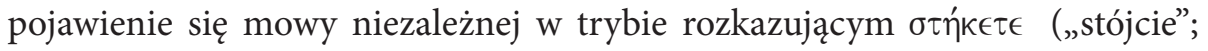
„trwajcie”; por 2,12). Spójnik $̋ ّ \sigma \tau \epsilon$ należy przetłumaczyć jako „więc”, „zatem” lub „przeto”. Chodzi tu o frazę podsumowującą wywód Apostoła skierowany

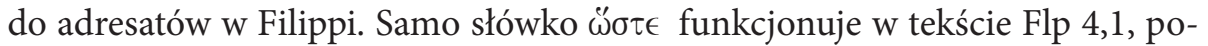
dobnie jak w 1 Tes 4,18, stanowiąc konkluzję perykopy. W Flp 4,2 św. Paweł rozpoczyna swoje pouczenie dla Kościoła, używając w tym celu czasownika $\pi \alpha \rho \alpha \kappa \alpha \lambda \hat{\omega}$ („wzywać), wskazując też na konkretne osoby: Ewodię i Syntychę. Czyni tak po raz pierwszy w tym liście. Podobnie jak w Rz 12,1, także w Flp 4,2 $\pi \alpha \rho \alpha \kappa \alpha \lambda \hat{\omega}$ wskazuje bez wątpienia na początek nowej części Pawłowego pisma. $\mathrm{Z}$ tych obserwacji literackich wynika jasno, że czwarta część probatio w Liście do Filipian rozpoczyna się w wierszu 3,1, a kończy w tekście 4,18.

Struktura wewnętrzna fragmentu probatio Flp 3,1-4,1 wskazuje na chiastyczny układ literacki tego fragmentu, oparty na klasycznym schemacie zestawionych ze sobą perykop A-B-B'-A':

A) 3,1-6: Apostoł rozpoczyna ten fragment Listu do Filipian od dwóch cza-

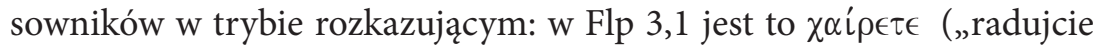
się"), a w 3,2 dwukrotnie użyty termin $\beta \lambda \epsilon ́ \pi \epsilon \tau \epsilon$ („strzeżcie się”, „uwa-

6 Zob. M. Theobald, Der Philipperbrief, s. 371-372.

7 Zob. R.P. Martin; G.F. Hawthorne, Philippians, s. 172-173.

8 Zob. J. Gnilka, Der Philipperbrief, s. 165. 
żajcie na"). Za pomocą tych dwóch imperatywów przekazuje Filipianom szczególny rodzaj ostrzeżenia. Powinni być czujni i uważni wobec nieprzyjaciół, którzy są przede wszystkim nieprzyjaciółmi Chrystusa. Chodzi tu o takich ludzi, którzy dają zły przykład i szerzą błędne myśli i zachowania, których nie wolno naśladować. Są nimi ci, którzy koncentrują się tylko na cielesnym wymiarze swego życia i chrześcijaństwa, którzy ufność pokładają w ciele 9 .

B) 3,7-11: Paweł Apostoł opowiada historię swojego życia i przedstawia swoje osobiste doświadczenie poznania Chrystusa. Ukazuje siebie jako kogoś, kto poświęcił wszystko, aby poznać Jezusa. Jeśli wcześniej pokładał ufność w tym, co cielesne $(3,4-6)$, to obecne ufa on tylko swemu Panu Jezusowi Chrystusowi. Tym razem chodzi o pozytywny przykład, polegający na osobistym upodobnieniu się do Mistrza.

B’) 3,12-16: Paweł kontynuuje osobisty dyskurs (nadal w pierwszej osobie liczby pojedynczej), przedstawiając siebie jako wzorcowy przykład dla chrześcijan w Filippi. Należy podkreślić, że w tym fragmencie chodzi o podobieństwo do Chrystusa w tajemnicy jego zmartwychwstania: „pędzę ku wyznaczonej mecie, ku nagrodzie, do jakiej Bóg wzywa w górę w Chrystusie Jezusie".

A') 3,15-4,1: W tym fragmencie autor powraca do dyskusji na temat nieprzyjaciół Chrystusa, czyli jego osobistych nieprzyjaciół i zarazem nieprzyjaciół samych adresatów listu. Paweł prosi, aby ich nie naśladować. Dodatkowo, właśnie w tym fragmencie probatio, św. Paweł precyzuje swoją doktrynę eschatologiczną, wskazując na znaczenie ludzkiego ciała w procesie zbawczym: Chrystus Pan przemieni obecne ciało podlegające śmierci na podobieństwo swojego uwielbionego ciała. Tak więc chiastyczny model struktury tekstu Flp 3,1-4,1 podkreśla znaczenie

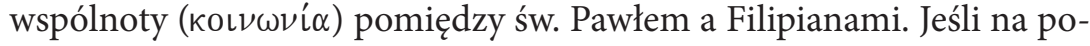
czątku tego fragmentu autor przedstawił sytuację adresatów pisma, to w jego zakończeniu opisany jest wspólny los, zarówno Apostoła, jak i wspólnoty chrześcijan w Filippi. Słowa otwierające list: $\tau \grave{\alpha} \quad \pi \epsilon \rho \grave{i}$ i $\mu \omega \hat{\omega} v$

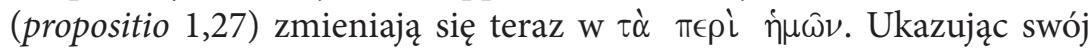
przykład człowieka wierzącego w Chrystusa, św. Paweł zdołał obudzić u chrześcijan w Filippi poczucie wspólnoty w Chrystusie, wybierając to zagadnienie na temat przewodni swego listu.

Uwzględniając dotychczasowe obserwacje możemy pokusić się o ustalenie wewnętrznej struktury całego probatio zawartego w Liście do Filipian 2,1-4,1:

9 Zob. O. Wischmeyer, Paulus. Leben-Umwelt-Werk-Briefe, s. 228. 
A. Losy Filipian 2,1-18:

a. 2,1-5: pokora Filipian,

b. 2,6-8: pokora Chrystusa,

b. 2,9-11: wywższenie Chrystusa,

a.' 2,12-18: wywyższenie Filipian.

B. Losy Tymoteusza 2,19-24.

B'. Losy Epafrodyta 2,25-29.

A'. Losy Filipian i Pawła Apostoła 3,1-4,1:

a. 3,1-6: nieprzyjaciele Filipian i ufność pokładana w ciele,

b. 3,7-11: pokora Pawła Apostoła,

b. 3,12-16: wywyższenie św. Pawła,

a'. 3,17-4,1: nieprzyjaciele krzyża; wiara w przemianę ziemskiego ciała ${ }^{10}$.

Powyższy schemat wydaje się pomocny w wyjaśnieniu myśli przewodniej św. Pawła zawartej w trzecim rozdziale Listu do Filipian. Ze względu na cierpienia znoszone dla Chrystusa i nadzieję zmartwychwstania, które po nich nastąpi, Apostoł ukazuje rzeczywistość krzyża Chrystusa w jego apostolskim życiu. Już w Flp 2,18 św. Paweł dawał Filipianom za przykład osobę Chrystusa jako jedyny godny do naśladowania: tylko Jezus Chrystus jest Panem niebios, tego, co na ziemi, i tego, co pod ziemią i nikt inny nie może zbawić człowieka. W 3,1-4,1 św. Paweł wzmacnia jeszcze bardziej swoje przesłanie: w tym fragmencie ukazuje on najpierw swoją głęboką jedność ze Zbawicielem (cierpi wraz z Chrystusem, aby poznać i doświadczyć mocy jego zmartwychwstania), a następnie swoją solidarność z Filipianami (ponieważ tak jak oni jest prześladowany ze względu na Chrystusa). W przedstawionym schemacie probatio widać doskonałą harmonię i równowagę literacką. Z jej pomocą Paweł wyjaśnia najgłębszą tajemnicę chrześcijańskiego życia, czyli Boga, który wzywa (powołuje) chrześcijan do wejścia w komunię z Jezusem Chrystusem przenikającą tak głęboko, że staje się jedynym centrum i źródłem ich życia. Podobne nauczanie prezentuje św. Paweł także w innych pismach:

Teraz zaś już nie ja żyję, lecz żyje we mnie Chrystus. Choć nadal prowadzę życie w ciele, jednak obecne życie moje jest życiem wiary w Syna Bożego, który umiłował mnie i samego siebie wydał za mnie. (Ga 2,20)

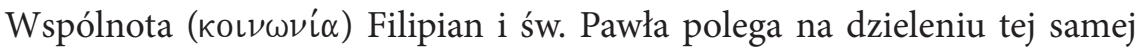
łaski, której Bóg udzielił Apostołowi (Flp 1,7). Osiąga ona swój szczyt w tekście 4,1: zarówno wysyłający list, jak i jego odbiorcy żywią głęboką nadzieję

10 Zob. O. Wischmeyer, Paulus, s. 228-229. 
na udział w tej samej chwale zmartwychwstania umarłych. Jeśli Chrystus już teraz żyje w nich, to w przyszłości przekształci ich ciała, kiedy powróci w swojej chwale.

\section{Nieprzyjaciele Filipian i ufność pokładana w ciele $(3,1-6)$}

Św. Paweł rozpoczyna swój wywód na temat rzeczy ostatecznych w Liście do Fi-

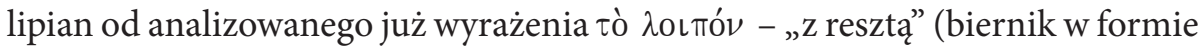
przyimka). Następnie dwukrotnie stosuje tryb rozkazujący $\chi \alpha i \rho \in \tau \in$ („radujcie się"; por. także 2,18). Powraca tym samym do jednego z najważniejszych teologicznych tematów swojego przesłania, istotnego także dla adresatów listu, pod-

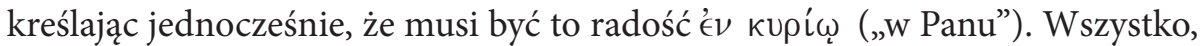
co czynią Filipianie (i chrześcijanie w ogóle), musi być dokonane w łączności z Chrystusem Zbawicielem. Pan jest dla nich jedynym źródłem radości, w przeciwieństwie do tych, którzy chcą wykrzywić przesłanie Ewangelii Jezusa ${ }^{11}$.

Bardzo szczególna jest druga część wiersza 3,1, czyli sintassi. Rozpoczyna

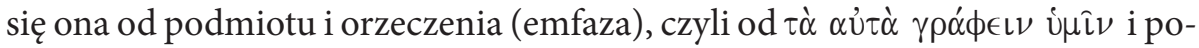
przedza wzmiankę o nadawcy i adresatach uwypukloną poprzez użycie party-

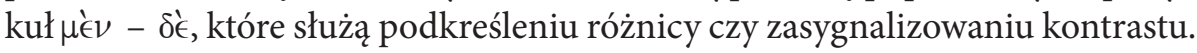
Są rzeczy, o których św. Paweł pisze bez obciążeń, a dla Filipinan są to informacje o wysokim priorytecie ${ }^{12}$. Cóż to są za rzeczy, sprawy bądź jak podają niektóre tłumaczenia „to samo”, które tak bardzo leżą Apostołowi na sercu? Chodzi o chrześcijan nawróconych z judaizmu, którzy upierają się za obrzezaniem wszystkich pogan nawracających się i przyjmujących naukę Jezusa Chrystusa. Paweł powtarza w treści tego pisma naukę, którą głosił, będąc osobiście w tej gminie, ponieważ zagadnienie jest bardzo trudne i palące, Apostoł przypomina o swoich wskazaniach i nic nie ujmuje z ich radykalności.

Wiersz drugi wskazuje na znakomite przygotowanie retoryczne św. Pawła. Rozpoczyna się on od anafory $\beta \lambda \epsilon \in \epsilon \epsilon \epsilon \in$ (trzykrotne użycie trybu rozkazującego) oraz o potrójnego uwypuklenia spółgłoski $\kappa$ (stoi na początku trzech kolejnych

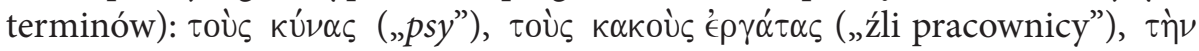
$\kappa \alpha \tau \alpha \tau o \mu \eta ́ \nu$ („okaleczeńcy”). Ci wymienieni przez św. Pawła w trzech grupach przeciwnicy prawdziwych chrześcijan ośmielają się polemizować sarkastycznie z judeochrześcijanami, którzy przepowiadali konieczność obrzezania po-

11 Zob. D.E. Garland, The Composition and Unity of Philippians, s. 144-145.

12 Szczegółową analizę na temat roli tekstu 3,1 w całości Listu do Filipian podaje: J.T. Reed, Philippians 3,1 and the Epistolary Hesitation Formulas: The Literary Integrity of Philippians, again, s. 72-87. 


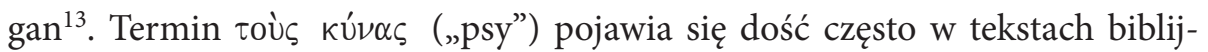
nych, przede wszystkim w ST (1 Sm 17,43; 24,14; 2 Sm 9,8; 16,9; 2 Krl 8,13) i posiada przeważnie negatywną konotację. Także cały współczesny Pawłowi świat greko-romański nienawidził psów, uważając je za zwierzęta brudne i niebezpieczne (agresywne). Słowo „pies” było więc raczej obelżywym epitetem, który św. Paweł wykorzystał jako formę ostrzeżenia kierowanego do adresatów

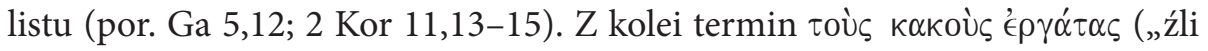
pracownicy"), znając zapalczywość Apostoła, zawiera tylko delikatną ironię co do braku zdolności przeciwników w wytrwałej pracy. Trzeci ironiczny ter-

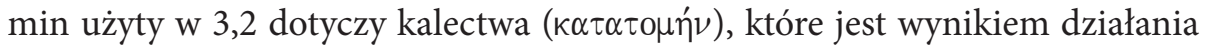
$\mathrm{z}$ przemocą wobec czyjegoś ciała. Jest to termin pejoratywny w przeciwieństwie do $\pi \epsilon \rho \iota \tau \mu \eta$, czyli właściwego obrzezania, które jest aktem religijnym zapewniającym zachowanie odpowiednich zasad higieny ${ }^{14}$. Przedrostek $\kappa \alpha \tau \alpha$ często

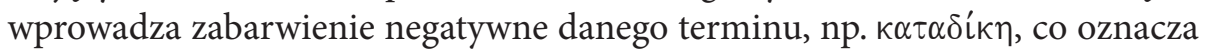
sentencję przeciwko komuś.

Zaimek osobowy $\dot{\eta} \mu \in \hat{\imath} \varsigma$, którym św. Paweł rozpoczyna wiersz 3,3, służy podkreśleniu różnicy, jaka istnieje pomiędzy Apostołem i Filipianami z jednej strony a ich nieprzyjaciółmi z drugiej. Przez użycie zaimka wadza w Flp 3,3 klimat głębokiej zażyłości i komunii między przesyłającym list a odbiorcami, która swoje źródło ma w nowym przymierzu Chrystusa. Objawia je Duch Jezusa. Fakt uczestnictwa w Nowym Przymierzu św. Paweł nazywa duchowym obrzezaniem, obrzezaniem serca. Tę samą doktrynę prezentuje także Rz 2,28-29: „... prawdziwym Żydem jest ten, kto jest nim wewnątrz, a prawdziwym obrzezaniem jest obrzezanie serca, duchowe, a nie według litery”. Poprzez użycie w dalszej części wiersza 3,3 czasownika $\lambda \alpha \tau \rho \in u ́ \omega$ św. Paweł, podobnie jak LXX, opisuje kult świątynny (Wj 23,25; Pwt 6,13; 10,12; Joz 22,27) ${ }^{15}$. Ponieważ chrześcijanie otrzymali już pierwsze dary Ducha św., są zdolni ofiarować swoje życie dla Pana (Rz 9,4; 12,1). Stają się prawdziwymi czcicielami Boga, oddając mu prawdziwą cześć w Duchu i w prawdzie (J 4,21). Wierzący w Chrystusa żyją według zasad Nowego Przymierza, które zainaugurował Jezus Syn Boży z pomocą i w mocy Duch św. Użyty w tym wierszu dopełniacz $\theta \in o ̂ ̂$ wyjaśnia pochodzenie Duch (jest on z Boga), jednocześnie Apostoł bardzo subtelnie zaznacza związek Nowego Przymierza ze Starym.

Dalsza cześć wiersza Flp 3,3 bywa błędnie tłumaczona. Interpretacja wy-

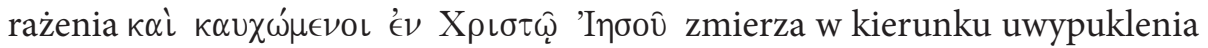
aspektu chwały, jaka płynie z przynależności do Chrystusa poprzez chrzest,

13 Zob. R.P. Martin; G.F. Hawthorne, Philippians, s. 173.

14 Zob. M. Theobald, Der Philipperbrief, s. 381-382.

15 Zob. R.P. Martin; G.F. Hawthorne, Philippians, s. 175. 


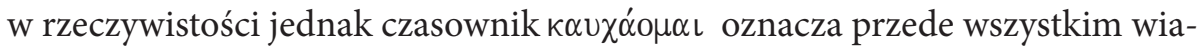
rę w kogoś lub bycie dumnym z kogoś. W przypadku św. Pawła i Filipian chodzi o bycie dumnym z samego Chrystusa. Ponieważ właśnie Jezus - Syn Boży - jest fundamentem nowego życia, Apostoł przywołuje Go w tym miejscu swojego wywodu, gdyż chce wyjaśnić także temat prawdziwej sprawiedliwości. Ma ona swoje źródło w wierze w Jezusa Chrystusa, a nie pochodzi z ciała. Dla Pawła najbardziej oczywistym znakiem sprawiedliwości mającej swoje źródło w tym, co cielesne, jest obrzezanie wynikające z litery Prawa.

Koniec tekstu Flp 3,3 św. Paweł prezentuje swoje spojrzenie na rzeczywi-

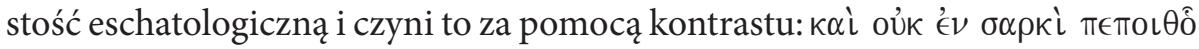
' $\tau € \varsigma . Z$ jednej strony stawia życie bez Chrystusa i życie w ciele, $z$ drugie zaś życie z Chrystusem i życie w Duchu. Chrześcijanin żyje na jednej z tych dróg: albo w ciele, albo w Duchu. Będą uczestnikiem Nowego Przymierza nie można żyć trochę ciałem i trochę Duchem (por. Ga 3,2-3). Chrześcijanin jest zatem zobowiązany do stałej weryfikacji swoich etycznych i moralnych postaw. Uzupełnieniem tej refleksji św. Pawła w Flp 3,3 jest wywód eschatologiczny Apostoła przeprowadzony w Rz 8,4-13: Tekst ten prezentuje zbawczy trynitaryzm: prawdziwa sprawiedliwość pochodzi od samego Boga, nowy kult i uwielbienie Boga pochodzi od Ducha św., a Nowe Przymierze inauguruje Jezus Chrystus, Syn Boży, przez swoją śmierć i chwalebne zmartwychwstanie (por. Flp 2,6-11) ${ }^{16}$.

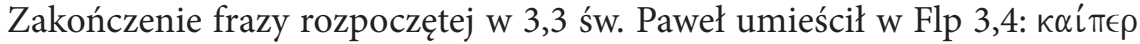

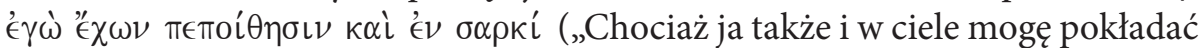

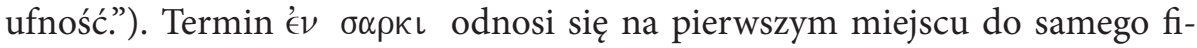
zycznego obrzezania ${ }^{17}$. W szerszym rozumieniu odnosi się do wszystkiego, co sprawia człowiekowi cielesną satysfakcję. Jeśli przeciwnicy Pawła chcą wygrać bitwę na tym poziomie, Apostoł Narodów jest gotowy na taką potyczkę także na podstawie tego, co cielesne. Powtórzenie w 3,4 części poprzedniego wiersza służy sprowokowaniu adwersarzy, a wyrażenie '́\} $\gamma \dot{\omega} \mu \hat{\alpha} \lambda \lambda \mathrm{ov}$ (,ja tym bardziej”) ukazuje porównanie $\mathrm{z}$ hipotetycznym rywalem ${ }^{18}$. Paweł uważa, że ma nad nim przewagę. Swoją pozycję ilustruje za pomocą siedmiu argumentów, które wyjaśniają jego zaangażowanie w całym sporze.

Pierwszym z nich jest obrzezanie - jeden z podstawowych tematów całego tekstu 3,1-4,1. Św. Paweł wie doskonale, o czym mówi i pisze, gdyż od pierwszych dni swego życia stał się członkiem wspólnoty Starego Przymierza, które Bóg zawarł ze swoim ludem. Nie ma wątpliwości, że jest on prawdziwie potomkiem Abrahama (Rdz 17,3-14). Drugim argumentem jest pochodzenie z ludu

16 Zob. G.D. Fee, Paul's Letter to the Phillippians, s. 302.

17 Zob. J. Gnilka, Der Philipperbrief, s.187.

18 Zob. R.P. Martin; G.F. Hawthorne, Philippians, s. 184. 


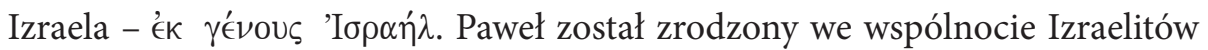
i posiada wszystkie przywileje wynikające z Przymierza zawartego na Synaju. Tak jak przez obrzezanie Paweł jest prawdziwym synem Abrahama tak przez zrodzenie we wspólnocie Przymierza jest prawdziwym synem Izraela. W dalszej kolejności Apostoł powołuje się na pochodzenie z pokolenia Beniamina ( $\phi \cup \lambda \hat{\eta} \varsigma \mathrm{B} \in \nu\llcorner\alpha \mu i \nu)$. Jest to dla niego kolejny powód do chluby. $Z$ tego pokolenia pochodził Saul - pierwszy król Izraela. Na terytorium tego pokolenia leżała Jerozolima, stolica najważniejszego monarchy w dziejach Izraela, Dawida. Króla, którego umiłował Bóg, z którym zawarł też Przymierze, składając mu jednocześnie obietnicę, że z jego potomstwa wyjdzie Mesjasz. Tym samym Paweł nie tylko stał się spokrewniony z królem, lecz także z przyszłym Mesjaszem.

Czwarty argument przytoczony przez św. Pawła dotyczy jego narodowości. Jest to wspólnota Żydów - Hebrajczyków. Paweł stwierdza z całą stanowczością,

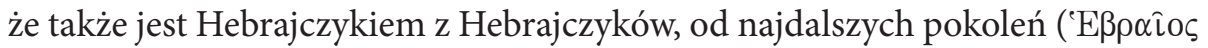

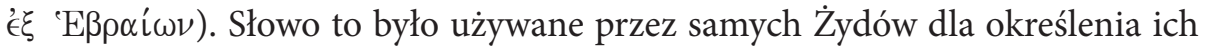
wyjątkowej tożsamości i etnicznego pochodzenia. Dla przeciwwagi poganie, których ST nazywa narodami, często stosowali termin "Judejczycy” na określenie członków wspólnoty narodu wybranego. W większości przypadków był to termin o pejoratywnym zabarwieniu ${ }^{19}$. Paweł mówiąc o sobie: „Hebrajczyk z Hebrajczyków" czuje się rzeczywiście kimś wybranym. Zamykające Flp 3,5

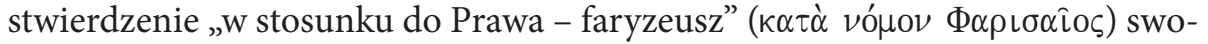
je potwierdzenie znajduje w świadectwach samego Apostoła $(\mathrm{Ga} 1,14)$ oraz św. Łukasza (Dz 23,6-9 i 26,5). Paweł był bardzo dumny z przynależności do tego stronnictwa, gdyż wyróżniało się ono szczególną miłością do Tory. Także i jego szacunek i miłość do Tory była bez zarzutu, choć dopiero na apostolskiej drodze odkrył on, że swoje wypełnienie ma ona w Jezusie Chrystusie, którego właśnie za brak respektu dla Prawa odrzucili przywódcy tego ugrupowania.

Wiersz 3,6 rozpoczyna się od Pawłowego potwierdzenia faryzejskiej gorliwości, której głównym przejawem było zaangażowanie $\mathrm{w}$ prześladowanie

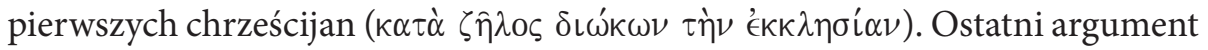
św. Pawła w sporze ze swoimi adwersarzami jeszcze raz dotyka kwestii związanych z Torą. Apostoł podkreśla, że co do respektowania i wierności dla jej zasad

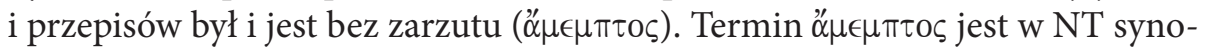
nimem doskonałości ${ }^{20}$. W wypełnieniu Prawa zatem niewielu może Pawłowi dorównać. Poświadcza, że zachowywał szabat oraz przepisy dotyczące czystości pokarmów. Sprawiedliwość, o jakiej mówi w tym tekście Apostoł, dotyczy rów-

19 Zob. J. Gnilka, Der Philipperbrief, s. 189.

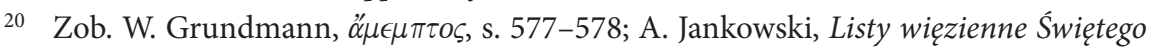
Pawła, s. 126. 
nież Tory i nie ma związku ze sprawiedliwością, którą daje wiara w Chrystusa. Sprawiedliwość, o jakiej wspomina Flp 3,6, odnosi się raczej do składanych ofiar (zwłaszcza pokarmowych) w kontekście najważniejszych świąt religijnych Izraela (por. Rz 14,17). Dotychczasowe życie św. Pawła w kontekście legalności prawnej jest zatem bez zrzutu. Jednak jest on również świadomy, że ta wierność Prawu w obliczu powołania i wiary w Jezusa Chrystusa jest pusta i próżna.

\section{Pokora Pawła Apostoła (3,7-11)}

W tekście 3,7 Apostoł rozpoczyna krótkie propositio, które kontynuuje w Flp 3,8-11. Tekst rozpoczyna się od wzmocnienia spójnikiem ' $\alpha \lambda \lambda \dot{\alpha}$ („,jednak”), a tym samym sygnalizuje zmianę argumentacji w całej sekcji 3,7-11. Służy on Pawłowi do zaprezentowania adresatom rezultatów swojego nawrócenia. Zgodnie z jego wyznaniem to Chrystus zmienił całkowicie wartości, którymi

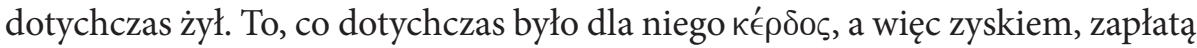
czy profitem, stało niczym innym jak stratą $(\zeta \eta \mu i \alpha)$. Jest to świadectwo człowieka, który potrafi zauważyć i wybrać to, co „lepsze” (por. Flp 1,10). Paweł zaprasza Filipian, aby dzielili teraz wraz z nim tę samą drogę. W tym zaproszeniu używa języka, który wywodzi się z handlu. Podobnie uczynił już wcześniej w Flp 1,21, gdzie stwierdził, że umrzeć oznacza zysk. Wróci do podobnej argumentacji jeszcze raz w peroratio zawartym w Flp 4,17-18: „...owocu, który wzrasta na wasze dobro. Stwierdzam, że wszystko mam, i to w obfitości: jestem zaopatrzony.... Apostoł nie odrzuca zatem swego żydowskiego dziedzictwa, ale nie jest ono dla niego żadnym powodem do chluby i zaszczytów.

Kolejny wiersz Flp 3,8 rozpoczyna się od wyjątkowej konstrukcji grama-

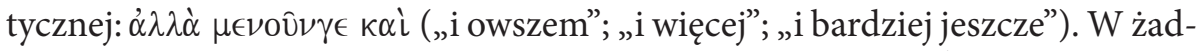
nym innym tekście NT nie spotykamy takiego układu słów. Św. Paweł rozpoczyna zatem wiersz 3,8 od hapax logomenon. W dalszej jego części powtarza drugą cześć poprzedniego wiersza: „ze względu na doniosłość (najwyższą wartość poznania Chrystusa, wszystko uznaję za stratę". Poznać Chrystusa oznacza zaufać $\mathrm{Mu}$, nawiązać z Nim relację, wierzyć, że On jest jedynym Zbawicielem. Św. Paweł ma w sobie ową wiarę: osobistą, głęboką i bardzo intymną, dlatego dodaje słowa: „mojego Pana”. Tymi słowami chce umocnić wiarę samych Filipian. Wiara Pawła jest wiarą, którą powinni posiadać i wyznawać adresaci listu, gdyż tylko Jezus Chrystus jest godny, aby go naśladować.

W drugiej części Flp 3,8 Apostoł powtarza swój temat straty wszystkie-

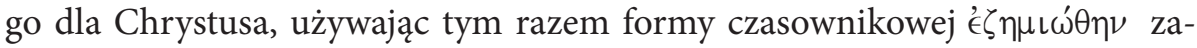
miast rzeczownika $\zeta \eta \mu i \alpha$. Natomiast terminem całkowicie nowym w słowniku św. Pawła i Listu do Filipian jest rzeczownik $\sigma \kappa u ́ \beta \alpha \lambda \alpha$. Zaskakuje zwłaszcza wul- 
garny wydźwięk tego słowa, które oznacza tyle co: „śmieci”, dokładnie wszelkie „odpady” i pozostałości po jedzeniu, które wyrzucano bezdomnym psom na ulicy. Tekstem o odpadach i śmieciach św. Paweł zwraca się ponownie do swoich przeciwników wzmiankowanych już w tekście Flp 3,2 $2^{21}$. Niektórzy bibliści tłumaczą słowo $\sigma \kappa u ́ \beta \alpha \lambda \alpha$ jako „gnój” czy „nawóz”. Jednakże pierwsza interpretacja oddająca termin $\sigma \kappa u ́ \beta \alpha \lambda \alpha$ jako „śmieci” wydaje się lepiej obrazować stan psychiczny i kontekst historyczny, w jakim znajduje się Apostoł. Po pierwsze rzeczownik „śmieci” bądź „odpady” lepiej uwydatnia kontrast pomiędzy obecnym życiem i postępowaniem św. Pawła w świetle nauki Chrystusa a poprzednim życiem, które opierało się na Torze. Po drugie termin $\sigma \kappa u ́ \beta \alpha \lambda \alpha$ dokładniej podkreśla kontrast pomiędzy dyskretną i delikatną miłością samego Chrystusa a nienawistną wulgarnością przeciwników Pawła. Ich błędne i gorszące postępowanie należy odrzucić za wszelką cenę, tak jak ludzie dobrze wychowani omijają śmieci i odpady na placach i ulicach miast ${ }^{22}$. Krótka propozycja, którą na końcu wiersza Flp 3,8 rozpoczynająca się od ¿̌ wuje najważniejsze pragnienie Apostoła Narodów: jedna rzecz, której pragnie, to zdobyć samego Pana Jezusa Chrystusa.

W wierszu 3,9 św. Paweł wyjaśnia, co oznacza według niego: „zyskać” lub

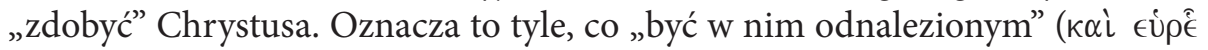

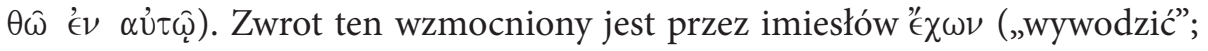
„pochodzić od kogoś lub czegos”"), który wyraża tę samą ideę, co pierwsza część wiersza Flp 3,9: Paweł jest obecnie cały zanurzony w Chrystusie, całkowicie pod jego wpływem i w komunii z Nim. W wierszu 3,9 zwraca również uwagę

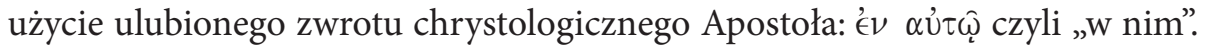
Podobne wyrażenia rozsiane są po całym Liście do Filipian: $1,13-\epsilon \nu$ X $\rho \iota \tau \hat{\omega}$,

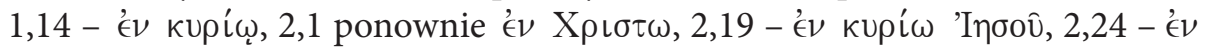

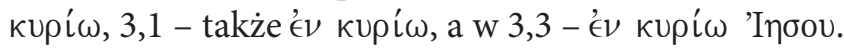

Druga część wiersza 3,9 rozpoczyna się od spójnika ả $\lambda \lambda \dot{\alpha}$, który podkreśla przeciwieństwo bądź przeciwstawną naturę omawianej kwestii. W tym przypadku chodzi o koncepcję sprawiedliwości w pojęciu św. Pawła, która jest diametralnie różna od tej, którą wyznają jego przeciwnicy przestrzegający legal-

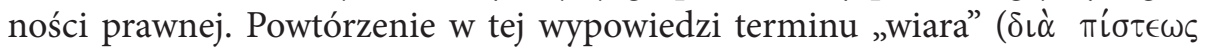

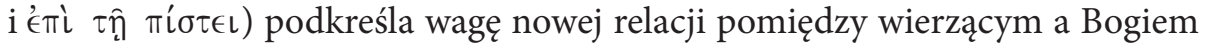
przez pośrednictwo Jezusa Chrystusa. Bóg ukazał swoją miłość dla grzeszników na krzyżu Chrystusa, natomiast wierzący chrześcijanie potwierdzają swoją miłość do Boga poprzez zawierzenie Synowi Bożemu, Jezusowi Chrystusowi. Nie chodzi tu o wiarę osobistą, wiarę pojedynczego chrześcijanina, lecz o wiarę

21 Zob. G. D. Fee, Paul's Letter to the Phillippians, s. 319.

22 Zob. F. Lang, $\sigma \kappa u ́ \beta \alpha \lambda \alpha$, s. 447; R.P. Martin; G.F. Hawthorne, Philippians, s.192. 


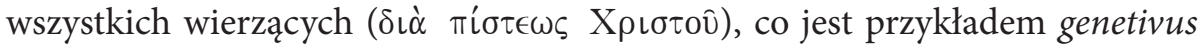
oggetivus: Chrystus jest przedmiotem wiary, tzn. my mamy wiarę w Niego, nie jest natomiast genetivus soggetivus, czyli nie chodzi o wiarę, którą posiada sam Chrystus ${ }^{23}$.

Tekst Flp 3,9 bardzo dobrze wyraża Pawłową koncepcję eschatologii, która przenika cały list: św. Paweł osobiście doświadcza wyjątkowej sprawiedliwości w Chrystusie, lecz zostanie odnaleziony przez samego Chrystusa ponownie w Dniu Pańskim (Flp 1,6; 2,16). Dla Apostoła sprawiedliwość jest efektem teraźniejszego stanu trwania w Chrystusie i przy Chrystusie, tymczasem zbawienie to stan przyszły i nie do końca znany ${ }^{24}$. Warto również zauważyć w tym miejscu, że doktryna eschatologiczna św. Pawła prezentowana w Liście do Filipian stoi w zgodzie z tym, co w kwestii eschatologii prezentuje List do Rzymian.

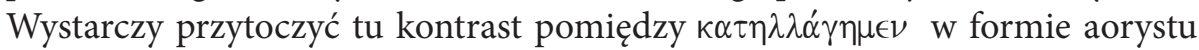
i $\sigma \omega \theta \eta \sigma o ́ \mu \epsilon \theta \alpha$ w formie pasywnej czasu przyszłego (Rz 5,10).

W kolejnym fragmencie 3,10 św. Paweł wraca do tematu poznania Jezusa Chrystusa. Według Apostoła poznanie Chrystusa ma swój aspekt teraźniejszy (ponieważ jesteśmy usprawiedliwieni, a zatem znajdujemy się w we właściwej, dokładnie sprawiedliwej relacji z Bogiem) i aspekt przyszły (ponieważ doświadczamy pełni zbawienia tylko w Dniu Ostatecznym ${ }^{25}$. W wierszu tym

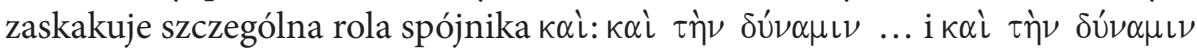
[...]. Można ją zinterpretować na dwa sposoby: 1) kał służy połączeniu z czasownikiem $\gamma \nu \hat{\omega} \nu \alpha \iota$ („znać”; „poznać”) trzech kolejnych dopełnień bliższych:

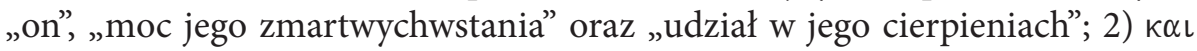
ma walor wyjaśniający (epsesgetico: wyjaśnia to, co następuje). W drugim przypadku chodziłoby tylko o dwa dopełnienia bliższe wspomnianego czasownika: „poznanie go (jego)” i „udział w”26. Wydaje się, że druga interpretacja jest bardziej przekonywająca, choćby ze względu na hymn chrystologiczny, który jest tekstem dominującym w całej strukturze Listu do Filipian (2,9-11 - ukazuje moc zmartwychwstania Pańskiego, a 2,6-8 wskazuje na jego cierpienia). Św. Paweł pragnie dzielić z Chrystusem obie rzeczywistości. Tego samego pragnie także dla samych Filipian. Poznanie Chrystusa, tzn. poznanie mocy jego zmartwychwstania, oznacza doświadczenie potęgi, którą Chrystus przekazuje na wierzących za sprawą Ducha (por. Rz 1,4). Co więcej, Apostoł pragnie cierpieć z Chrystusem, mieć w udział w Jego cierpieniach: cierpieć z Chrystusem bowiem jest integralną częścią chrześcijańskiego życia (por. 1 Tes 1,6; 3,2-3; 2

Zob. G.D. Fee, Paul's Letter to the Phillippians, s. 325.

Zob. M. Theobald, Der Philipperbrief, s. 387.

Zob. J. Gnilka, Der Philipperbrief, s. 209.

Zob. R.P. Martin; G.F. Hawthorne, Philippians, s. 197 
Kor1,5; 4,7-18; Rz 8,17). Paweł ukazuje zatem, poprzez przykład swego życia, to wszystko, co zapowiedział w propositio ze względu na Filipian: „Wam bowiem z łaski dane jest dla Chrystusa: nie tylko w Niego wierzyć, ale i dla Niego cierpieć" $(1,29)$.

W zakończenie wiersza Flp 3,10, poprzez zastosowanie imiesłowu $\sigma u \mu \mu о \hat{\rho}$ $\phi \iota \zeta o ́ \mu \in \nu \circ \varsigma$ („upodobnić się”, „stać się podobnym”) św. Paweł tworzy połączenie semantyczne z tekstem Flp 2,6-8. Wspomniany imiesłów odwołuje się do wy-

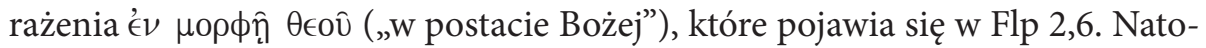

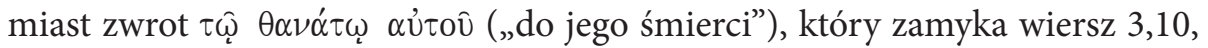

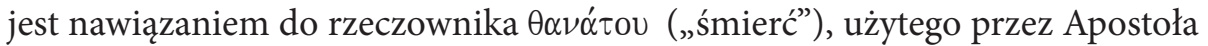
dwa razy w Flp 2,8. Tworząc powyższe połączenie semantyczne pomiędzy Flp 2,6-8 a 3,10, św. Paweł chce wyrazić następującą prawdę: jeśli Chrystus jest

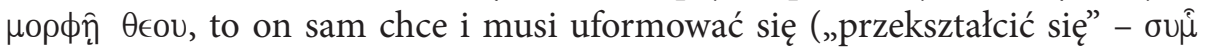
$\mu о \rho \phi i \zeta(\omega)$ na obraz swojego Pana Jezusa Chrystusa. On jest jedyną przyczyną jego radości, a także jego kajdan i prześladowań, które przyjmuje z godnością ${ }^{27}$. Obraz ten jest jeszcze jednym przykładem Pawłowego rozumienia słowa коเ $\nu \hat{\omega}$ ví („wspólnota”).

Św. Paweł sądzi, że skoro w czasie teraźniejszym dzieli z Chrystusem jego cierpienia, to w przyszłości będzie także współuczestnikiem jego zmartwychwstania. Pojawiający się zatem w 3,11 zwrot €ll $\pi \omega \varsigma$ („w jakiś sposób”; ,jakoś”) nie wyraża wątpliwości ze strony Apostoła w tajemnicę zmartwychwstania. Przeciwnie, podkreśla łączność z prawdą, którą właśnie wyraził: bez śmierci dla Chrystusa nie ma zmartwychwstania z Chrystusem. Te dwie rzeczywistości uzupełniają się wzajemnie, a wiersz Flp 3,11 tworzy rodzaj pomostu literackiego, łącząc się tematycznie z treścią, którą Paweł zawarł w dalszej części listu.

\section{Wywyższenie św. Pawła $(3,12-16)$}

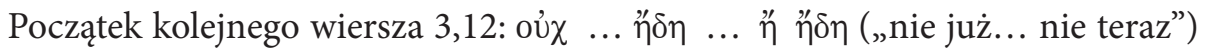
kreśli perspektywę przyszłego, osobistego zbawienia Apostoła. Jeśli fragment Flp 3,7-11 dotyka tego, co „już" się dokonuje, to tekst 3,12-16 rozwija temat tego, co w teologii nazywamy ,jeszcze nie" (" $\delta \eta$ - powtórzone dwa razy w 3,12). Dla właściwego zrozumienia 3,12 istotne jest także właściwe zrozumienie czasowników użytych przez św. Pawła w tym wierszu. Pierwsza forma, czyli ' $€ \alpha \propto \beta \nu \nu$, jest aorystem, który należy przetłumaczyć w sensie „ja jeszcze nie osiągnąłem”, natomiast $\tau \in \tau \in \lambda \in i \omega \mu \alpha \iota$, (tzw. perfectum passivum, $\tau \in$ '́ $\lambda \circ \varsigma$ - „koniec”, „meta”, „cel”), oznacza ,ja jeszcze nie osiągnąłem celu (mety)”. Czasow-

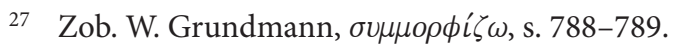


nik $\tau \in \tau \in \lambda \in i \omega \mu \alpha \iota$, nie ma dopełnienia. Należy zatem zapytać, o czym św. Paweł mówi w 3,12? Jedną z możliwości interpretacyjnych jest odwołanie się do tego, czego św. Paweł dotykał we wcześniejszej sekcji 3,10-11, czyli o jego znajomość Chrystusa. Paweł pozna w pełni Chrystusa dopiero w przyszłości, w momencie, który określa jako eschaton.

Czasownik $\delta\llcorner\omega ́ \kappa \omega$ „wysilam się”; „dążę do, ku”, który otwiera drugą cześć Flp 3,12 nawiązuje do terminologii sportowej. Jakkolwiek Apostoł nie osiągnął jeszcze celu swego biegu życia, to jednak w wysiłek wkłada całą dostępną energię. Kolejny czasownik $\kappa \alpha \tau \alpha \lambda \alpha \alpha \beta \omega$ „zdobyć”; „osiągnacć” nie posiada dopełnienia. Zostało ono zastąpione zaimkiem względnym, poprzez połączenie (fuzję) zaimka względnego i wskazującego. Nie przez przypadek pytanie, „dlaczego” Paweł został pochwycony, zostaje zastąpione formą zaimkową ' $\phi$ ' $\hat{\omega}$ („,to przez

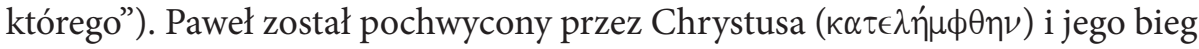
ku zbawieniu jest możliwy, ponieważ Zbawiciel - Jezus Chrystus jest prawdziwie aktywnym, działającym w jego życiu. Apostoł nie czyni nic innego, jak tylko odpowiada pozytywnie na inicjatywę Syna Bożego.

Wołacz, od którego św. Paweł rozpoczyna kolejny wiersz: $\alpha \delta \in \lambda \phi o i ́ ~(3,13)$, przypomina o tym, że wszystko, cokolwiek św. Paweł pisze, ma na celu dobro adresatów, jego „braci” w Chrystusie. Są oni złączeni z osobistą historią św.

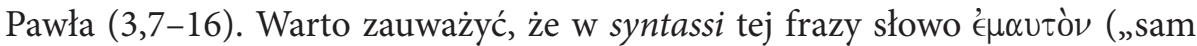
o sobie”; „sam w sobie”) jest podmiotem bezokolicznika perfectum $\kappa \alpha \tau \epsilon \iota \lambda \eta \phi \tilde{\epsilon}$ " $\nu \alpha \iota \cdot($ „chwycić”; „złapać”). Paweł zmienił w tym zdaniu pozycję zaimka osobowego, aby podkreślić swoją rolę w całej inicjatywie eschatologicznej kierowanej do Filipan. Nie chodzi o to, by się od nich odróżnić, lecz o głęboki akt pokory Apostoła: „nie twierdzę, że już zostałem pochwycony”. Jeszcze raz Paweł podkreśla niezwykłą i tajemniczą siłę wewnętrzną, która, przenika jego wnętrze i przemienia go na podobieństwo starzały wypuszczonej przez niebieskiego łucznika, by dotrzeć do zbawczego ideału.

W kolejnych słowach listu $(3,13 b)$ św. Paweł prezentuje siebie jako kogoś, kto walczy na arenie, $\mathrm{w}$ wymagających zawodach, aby zdobyć miejsce $\mathrm{w}$ wiel-

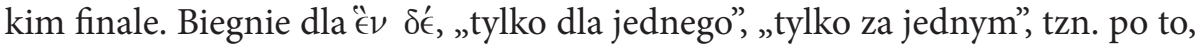
by poznać w pełni Jezusa Chrystusa. Apostoł koncentruje się tylko na tym, co przed nim. Nie skupia uwagi na sprawach przeszłych (odniesienie do chwil, kiedy szukał sprawiedliwości tylko w przepisach Prawa - 3,4-8), lecz dokłada wszelkich sił, aby dotrzeć do nowego celu. Kolejny wiersz 3,14 dokładnie wy-

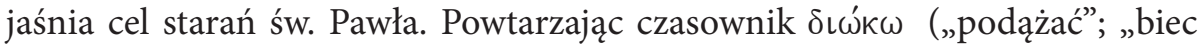
w kierunku”; „biec za”), Apostoł mówi jasno, że celem biegu, który podjął, jest nagroda. Jest to dla Pawła premia wyjątkowa. Chodzi o Boże powołanie (genetivus soggetivus), w łączności, w komunii z Chrystusem. Jest jednocześnie zaproszenie, aby wejść, wspiąć się $\alpha^{\prime} \nu \omega$, czyli „wysoko”, „w stronę nieba”, do domu 
Boga. Św. Paweł odwołuje się tu do „porwania” wierzących na obłoki w dzień Chrystusa, kiedy to wierzący w Niego będą na zawsze przebywać z Bogiem (por. 1 Tes 4,16-17) ${ }^{28}$.

Następne słowa listu wyrażają najgłębsze pragnienie św. Pawła skierowane do Filipian: winni oni przede wszystkim pozostać jednomyślni. Wyrażający tę myśl czasownik został użyty w pierwszej osobie liczby mnogiej. Paweł jednoczy się z Filipianami, wyrażając tę ideę za pomocą terminu $\tau^{\prime} \dot{\lambda} \lambda \in \operatorname{lol}(3,15)$. Jest to nawiązanie do tekstu Flp 3,12, na początku tej sekcji, gdzie użyty został czasownik $\tau \in \tau \in \lambda \in i \omega \mu \alpha \iota$ („zakończyć”; „dotrzeć do celu”). Jeśli nie jest on jeszcze $\tau \in \in \in \in(O \varsigma$, , to dlatego, że nie dotarł jeszcze do celu swojej nadziei w niebie, ale z drugiej strony już nim jest, gdyż doświadcza sposobu myślenia i życia Filipian

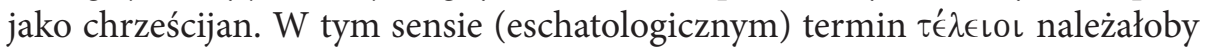
tłumaczyć jako „dojrzali”, nie „doskonali”, ponieważ św. Paweł sam w swoich pismach nigdy nie pretenduje do bycia po ludzku doskonałym.

Swój wywód o doskonałości Paweł zamyka, dokonując pewnej klasyfikacji.

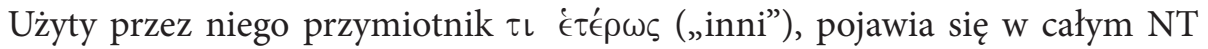
tylko w tym tekście. Są więc niektórzy Filipianie myślący inaczej. Niektórzy komentatorzy znajdują w tej wypowiedzi św. Pawła aluzję sugerującą istnienie pewnej stałej grupy Filipian stojących w jawnej opozycji do poglądów i osoby Apostoła. Jednak ta idea nie ma potwierdzenia w samej treści listu, a także w innych pismach św. Pawła. Przeciwnie, Apostoł na każdym kroku podkreśla ogromną sympatię i przyjaźń, jaka łączy go z tą właśnie gminą. Nawet jeśli są takowi, którzy myślą inaczej, to Paweł jest przekonany, że sam Bóg pobudzi ich do poznania prawdy ${ }^{29}$. Ten proces sugeruje użycie czasownika $\dot{\alpha} \pi \circ \kappa \alpha \lambda \hat{u}$

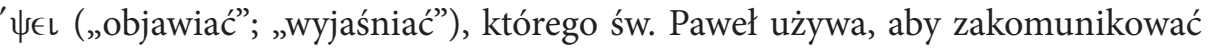
o Bożym objawieniu (Rz 1,18; 8,18; 1 Kor 2,10; 14,30; Ga 1,16; 3,23). Apostoł jest więc przekonany, a wręcz pewny, że wobec wątpiących, Bóg objawi to, co konieczne dla dobra swojego Kościoła. Mamy tu zatem do czynienia $\mathrm{z}$ aktem wiary ze strony Pawła, który z jednej strony ufa Bogu, z drugiej członkom gminy w Filippi: Bóg okaże się wierny wobec swego Kościoła, a Filipianie dyspozycyjni i otwarci, by przyjąć Boże pouczenie. Tym samym tekst 3,15 ponownie

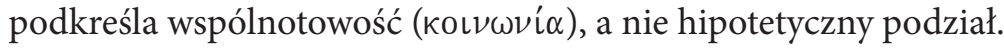

29 Zob. G.D. Fee, Paul's Letter to the Phillippians, s. 327. 


\section{Nieprzyjaciele krzyża i wiara w przemianę ziemskiego ciała $(3,17-4,1)$}

Stosując formy liczby mnogiej, św. Paweł podejmuje w swoim piśmie kwestię sposobów działania użytecznych dla Filipian, aby poznać Chrystusa i osiągnąć zbawienie. W zakończeniu kolejnej sekcji Paweł dotyka zatem zagadnień etycz-

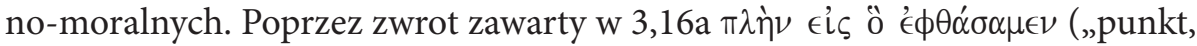
do którego doszliśmy”), Apostoł Narodów określa dystans, który przebył razem $\mathrm{z}$ adresatami listu, tzn. progres, jaki dokonał się $\mathrm{w}$ ich naśladowaniu i podążaniu za Chrystusem Zbawicielem. W tym miejscu wypada postawić pytanie, do czego odnosi się w tym tekście termin $\tau \hat{\omega} \alpha$ $\alpha \tau \hat{\jmath}$ („to samo”)? Wydaje się, że św. Paweł wraca tu do podobnego zwrotu, który pojawił się na samym początku

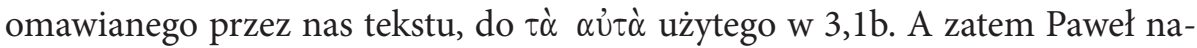
wiązuje do tego wszystkiego, czego nauczał, będąc w Filippi. Cała sekcja kończy się apelem, bądź stanowi echo odwołujące się do pierwszych inicjatyw Apostoła. Bezokolicznik $\sigma \tau o \iota \chi \in \hat{\imath} \nu$ (dosł. „podążać po tej samej linii w czasie bitwy”) ma u Pawła walor wychowawczo-pedagogiczny (exortativum) i znaczy tyle, co „działać w zgodzie z"30. Teksty Ga 5,25 i 6,16 wyjaśniają dokładniej, co Apostoł

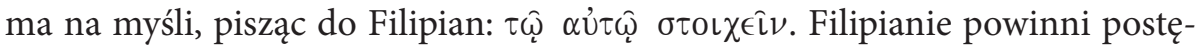
pować i żyć zgodnie z duchem Ewangelii Chrystusa według pouczenia, jakie daje Duch św. Bóg objawia zatem Filipianom swoją wolę przez swojego Ducha.

Dwa czasowniki, które św. Paweł umieścił na początku kolejnego wiersza:

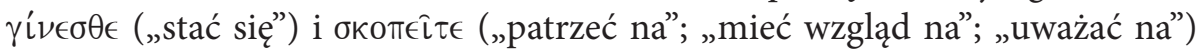
mają formy trybu rozkazującego. Ta zmiana form gramatycznych sugeruje pojawienie się nowej sekcji literackiej w tekście listu. Połączenie wspomnianych form czasownikowych z rzeczownikiem „bracia” ( $\alpha \delta \in \lambda \phi o i ́)$ odwołuje do początkowej wypowiedzi w tym rozdziale $(3,1-6)$, czyli do czasowników: $\chi \alpha i ́ \rho \epsilon \tau \epsilon$

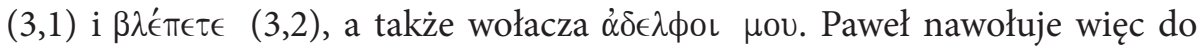
tego, aby Filipianie naśladowali go, a także wszystkich tych, którzy podążają tą samą drogą za Chrystusem co Apostoł. Jako dobre przykłady do naśladowania wymieniał on już wcześniej Tymoteusza $(2,19-24)$ i Epafrodyta $(2,25-29)$, a w 3,17 samego siebie stawia jako przykład, za którym warto podążać. Wystę-

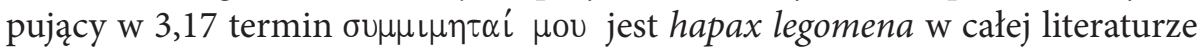
greckiej. Oznacza on po prostu imitację, bądź naśladowanie kogoś. Przedrostek $\sigma u \mu$ odwołuje się do osobistego nauczania św. Pawła, który chce powiedzieć, że dla Filipian konieczne jest nie tylko bycie naśladowcą św. Pawła, lecz przede wszystkim bycie razem $\mathrm{z}$ nim, zachowanie z nim wspólnoty. Po raz ko-

30 Zob. G.D. Delling, $\sigma \tau o\left\llcorner\chi \chi^{\prime} \omega\right.$, s. 668. 


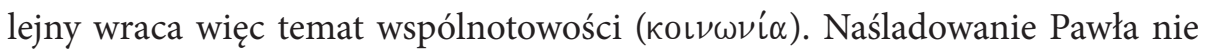
jest jednak celem samym w sobie. Ma ono zawsze prowadzić do Chrystusa, jedynego Mistrza i Zbawiciela. Paweł mówił już o tym dobitnie w Flp 2,5 (por. także 1 Tes 1,6). Chodzi tu o etyczną drogę chrześcijanina (wyraża to imiesłów $\pi \epsilon \rho \iota \pi \alpha \tau o \hat{\nu \tau \alpha \varsigma ~-~ „ i d a ̨ c ” ; ~ „ p o d a ̨ z ̇ a j a ̨ c ”) ~ i ~ o ~ z a c h o w a n i e, ~ k t o ́ r e ~ P a w e ł ~ n a z y w a ~ „ z ̇ y-~}$ ciem według Ducha" (Rz 8,4; Ga 5,16). Kończąc wywód na temat naśladowania Chrystusa, Apostoł Narodów przyszywa swoich pomocników w trudzie głosze-

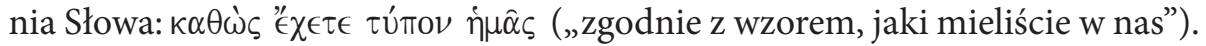
Tekst odnosi się przede wszystkim do wzmiankowanych już: Tymoteusza i Epafrodyta. Św. Paweł w swoich pismach zawsze pozostaje w łączności ze swoimi współpracownikami i przyjaciółmi.

Aby uwydatnić kontrast wobec tego, co właśnie zostało powiedziane, św. Paweł wraca do wcześniej poruszanych argumentów o przeciwnikach Ewangelii. Poprzez zastosowanie krótkiego yà $\rho$ (,jednak”) prezentuje powody, dla któ-

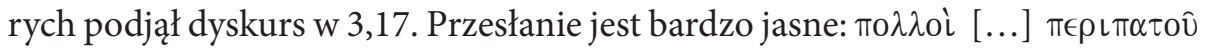
$\sigma \iota \nu$ - „liczni (wielu) ... podążają (kroczą)” jako nieprzyjaciele krzyża Chrystusowego. Ci oczywiście nie są godni naśladowania. Owi „liczni” nie są członkami Kościoła, lecz sympatykami Żydów, którzy przyczynili się do wielu cierpień zadanych Pawłowi i mogą w przyszłości zagrozić także samym Filipianom ${ }^{31}$. Dodatkowo w 3,18 pojawiają się nawiązania do innych zagadnień, które św. Paweł poruszał już wcześniej w Flp 3. Przede wszystkim powraca idea sprawiedliwości. O ile chodzi o przeciwników Apostoła, to są oni zdecydowanymi wrogami Chrystusa. Ich doktryna i ich błędne postępowanie dążą do zanegowania krzyża Zbawiciela - jedynego źródła usprawiedliwienia (por. 1 Kor 1,17-25). Ze względu na tę okoliczność obrazy krzyża i samego Chrystusa Paweł odczuwa silny ból, pisząc o tym w sposób otwarty do Filipian. Użycie przez niego

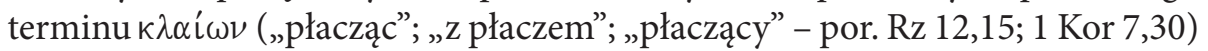
nie pozostawia wątpliwości. Apostoł Narodów nigdy nie ukrywa swoich uczuć, tak wobec przyjaciół (współpracownicy; Filipianie), jak i przeciwników („nierozumni Galaci”; „przeciwnicy krzyża”). Wszyscy oni dobrze wiedzą, jak św. Paweł żyje, czuje i myśli. Przede wszystkim z przyjaciółmi dzieli wszystko tak, jak to czyni prawdziwy przyjaciel.

Przemawiając $\mathrm{w}$ dalszym ciągu do swoich przeciwników Paweł przepowiada ich całkowity upadek. Użyty w 3,19 rzeczownik $\tau$ '́ $\lambda$ os (warto zwrócić uwage

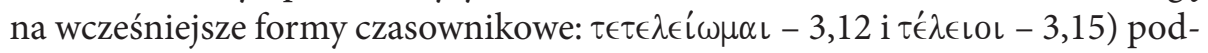
kreśla aspekt eschatologiczny całego fragmentu. Koniec przeciwników Pawła

31 Odmiennego zdania jest G.D. Fee, który twierdzi, że owi „liczni” w 3,18 to źli pracownicy i tzw. psy (wzmiankowani już wcześniej przez Pawła w Flp 3,2). Zob. G.D. Fee, Paul's Letter to the Phillippians, s. 328. 
i Filipian jest całkowicie różny. O ile ci pierwsi zmierzają w stronę zbawczej szczęśliwości, drudzy - przeciwnicy krzyża Chrystusowego - w stronę zatracenia. Użyty na określenie zguby i hańby przeciwników Pawła rzeczownik $\alpha \pi \omega ́ \lambda \hat{\epsilon}$ $\iota \alpha$ oznacza całkowitą zagładę, wieczną zatratę. W sensie metaforycznym termin ten oznacza całkowity brak (absencję) Boga. Jest więc synonimem śmierci ab-

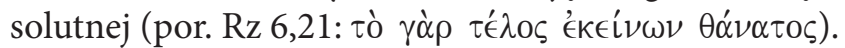

Przeciwnicy krzyża Chrystusowego odrzucili nie tylko samego Zbawiciela, lecz także Boga, który Go posłał. Teraz Paweł stwierdza, że ich bogiem stał się

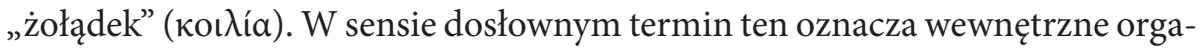
ny człowieka odpowiedzialne za procesy trawienne (wnętrzności). Podobnego sformułowania Apostoł używa w Rz 16,18 i 1 Kor 16,18. Można założyć, że Paweł poprzez użycie rzeczownika кoเ $\lambda i ́ \alpha$ odwołuje się do wszelkich przepisów pokarmowych zapisanych w Torze. Były one dla Żydów szczególnie ważne. Żołądek jest jednak symbolem apetytu i pożądania pokarmu, często nieokiełznanego, oraz wyraża pragnienie posiadania jak największej ilości dóbr tego świata. Na pierwszym miejscu stoi zawsze pokarm, ale odwołuje się on także do innych pragnień cielesnych. Św. Paweł chce zatem podkreślić, że źli pracownicy ograniczyli swoją aktywność do pragnień tego świata i pożądań ludzkiego ciała. Nie są w stanie dostrzec innych wymiarów, tak jak to czyni Paweł i jego współpracownicy. Dlatego odrzucają Boży plan zbawienia, który został najlepiej objawiony w tajemnicy zmartwychwstania Chrystusa.

Zamiast celebrować chwałę Bożą, przeciwnicy krzyża świętowali własną chwałę, co przywiodło ich do katastrofalnych rezultatów. Paweł wyraża to jednym zdaniem: ich chwała jest w ich wstydzie (w tym czego powinni się wstydzić). Ci ludzie są grzesznikami, a życie w grzechu jest życiem pełnym wstydu

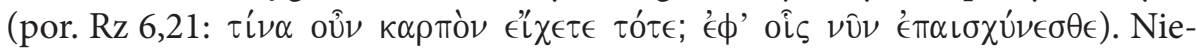
którzy bibliści uważają, że mówiąc o rzeczach wstydliwych, św. Paweł odwołuje się do obrzezania. Jednak trudno zgodzić się z tym poglądem, gdyż Apostoł z żadnym ze swoich pism nie określił obrzezania rzeczą wstydliwą. Kontekst wypowiedzi jest raczej etyczny niż prawny. Paweł uważa ich zachowanie jako chrześcijan za wstydliwe (zawstydzające). Szczycą się oni bardziej sprawiedliwością wynikającą z Prawa, aniżeli tą, która pochodzi wprost z wiary w Chrystusa Pana (por. 3,9).

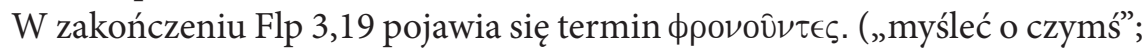
„mieć coś w świadomości”). Jest to jeden z najważniejszych czasowników całego listu. Apostoł użył go już wcześniej w odniesieniu do Filipian $(2,2-5)$ i w odniesieniu do siebie samego $(3,15)$. Teraz stwierdza, że przeciwnicy krzyża myślą tylko o sprawach przyziemnych. Paweł skoncentrowany jest na sprawach nieba $(3,14)$, skąd przybędzie kiedyś jego Pan, Jezus Chrystus. Jego przeciwnicy zarzucili bieg w kierunku rzeczy, które są w górze, zadowalając się tylko co 
proponuje świat. Kontrast, jaki istnieje pomiędzy tym, co w niebie, a tym, co na ziemi, Paweł naświetla w innych tekstach swoich listów (por. 1 Kor 15,40; 2 Kor 5,1). Przemija postać tego świata, a więc lepiej według św. Pawła, myśleć o Jezusie Chrystusie Zbawicielu.

Zaimek osobowy $\dot{\eta} \mu \omega \hat{\nu}$ na początku nowej frazy wyraża kontrast pomiędzy Pawłem i Filipianami a ich przeciwnikami. Apostoł wraca tym samym do jednego z głównych zagadnień swego pisma: do wspólnych losów Filipian i wła-

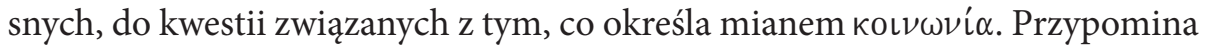
Filipianom, że ich wspólna ojczyzna jest w niebie. Użyty tu rzeczownik то $\lambda \hat{i}$ ' $\epsilon \cup \mu \alpha$ („rzecz publiczna”; „obywatelstwo”; „ojczyzna”) przywodzi na myśl podobnie brzmiący termin („prowadzić się”; „zachowywać”; „żyć według zasad”), który pojawił się na początku listu $(1,27)$. Ich użycie przywołuje ponownie problematykę eschatologiczną. Filipianie, podobnie jak Paweł, żyją podwójnym obywatelstwem, które najlepiej wyraża zwrot: „już i jeszcze nie”. Z jednej strony ich życie nasycone jest poważnymi wymaganiami etyczno-moralnymi, z drugiej przepełnia ich nadzieja na przyszłe spotkanie z Panem w wiecznej szczęśliwości. Pierwsza część etyczno-moralna zmierza do nieuchronnego końca, druga będzie trwać wiecznie. W Flp 3,20 św. Paweł kładzie nacisk na fakt przynależności Filipian do społeczności wybranych, którzy już teraz są obywatelami nieba, chociaż muszą jeszcze, tak jak i on sam, wyczekiwać ostatecznego wypełnienia się Bożej obietnicy zbawienia ${ }^{32}$.

O ile tekst Flp 3,20a dotyka tych rzeczywistości, które można nazwać owym „już”, o tyle Flp 3,20b-21 koncentruje się na tym, co czeka chrześcijan w przyszłości. Wiersz 3,21 rozpoczyna się od zaimka względnego ös („który”), za pomocą którego Paweł chce zademonstrować sposób, w jaki Chrystus będzie działał przy końcu czasów. Idea, którą prezentuje w tym tekście św. Paweł, jest bardzo podobna do przesłania zawartego w 1 Kor 15,42-57. Apostoł prze-

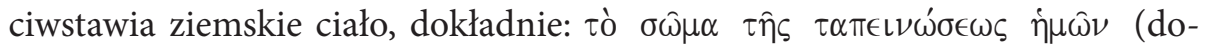
kładnie: „ciało naszego poniżenia”), ciału, które będzie na podobieństwo ciała

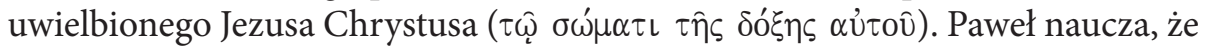
Chrystus przekształci obecne ciało (w 1 Kor 15 - „ciało naturalne”) w przyszłe ciało (w 1 Kor 15 - „ciało duchowe”) w chwili zmartwychwstania. Czasownik $\mu \epsilon \tau \alpha \sigma \chi \eta \mu \alpha \tau i ́ \sigma \in \iota$ użyty został w formie czasu przyszłego, aby zademonstrować, że mowa jest o akcji, która dopiero nadejdzie. Termin ten oznacza dokładnie zmianę jakiejś trwałej formy, a więc Chrystus zmieni formę ludzkiego ciała, aby uczynić je podobnym do swojego nowego chwalebnego ciała. Użyte w 3,21 formy $\mu \epsilon \tau \alpha \sigma \chi \eta \mu \alpha \tau i ́ \sigma \in \mathrm{l}$ i $\sigma u ́ \mu \mu о \rho \phi o \nu$ nawiązują do hymnu chrystologicznego

32 Zob. N. Walter, Die Philipper und das Leiden. Aus der Anfängen einer heidnischen Gemeinde, s. 421-424. 
w Flp 2,6-8. Ostatecznie przesłanie Flp 3,21 można zamknąć w stwierdzeniu, że wierzący w Chrystusa podzielą los swojego Zbawiciela: zarówno On jak i Filipianie otrzymają nowe ciało, które jest potrzebne dla przyszłej, nowej egzystencji w niebie.

Druga część Flp 3,21 wyjaśnia kwestie podjęte w 3,21a. Zaskakuje fakt, że w tym tekście św. Paweł używa terminologii, którą do tej pory ograniczał tylko

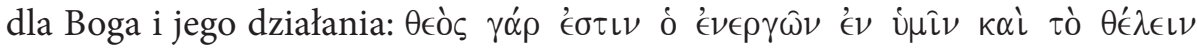

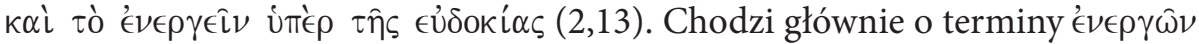

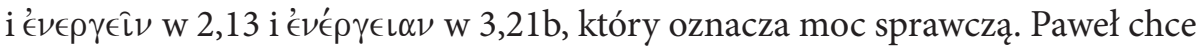
powiedzieć, że moc Boża obecna w świecie (jak to wyraża Flp 2,13) została już przekazana Chrystusowi w 3,21b. Chrystologizacja mocy Bożej jest typowym zabiegiem w teologii św. Pawła i jest całkowicie zgodna z jego doktryną: „A gdy już wszystko zostanie Mu poddane, wtedy i sam Syn zostanie poddany Temu, który Synowi poddał wszystko, aby Bóg był wszystkim we wszystkich" (por. 1 Kor 15,28).

Jak wynika z przeprowadzonej analizy dotyczącej struktury wewnętrznej Listu do Filipian, wiersz 4,1 kończy Pawłowe probatio, a dokładnie jego czwartą część. Jest on jednocześnie podsumowaniem całego pouczenia, które św. Paweł chciał przekazać Filipianom na kartach swego przyjacielskiego listu. Zawiera on bardzo osobiste wyznanie Apostoła. Czasownik $\sigma \tau \eta \dot{\kappa} \in \tau \epsilon \mathrm{w}$ formie trybu rozkazującego nawiązuje do wypowiedzi zawartej w propositio $(1,27)$. Przez użycie tego terminu Paweł chce podkreślić, że trwanie mocno przy Chrystusie, nawet w obliczu prześladowań i zachęta do tej postawy kierowana do Filipian, jest fundamentalnym tematem całego fragmentu Flp 3,1-4,1. Filipianie muszą pozostać silni w Panu, który na pewno przyjdzie. Jakkolwiek 4,1 jest pouczeniem zbiorowym, to przygotowuje indywidualne wskazówki, jakich Paweł będzie udzielał poszczególnym osobom, poczynając od tekstu Flp 4,2. Cały fragment probatio kończy się zatem słowami o przyjaźni i wzajemnym przywią-

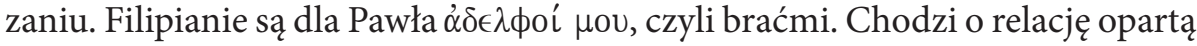

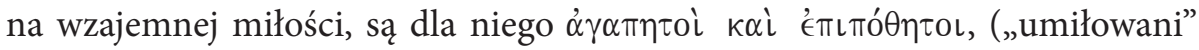
i „upragnieni”). Są jego radością i koroną apostolskiego wysiłku, dzieląc z nim ten sam los. Będąc w więzieniu, św. Paweł odkrył prawdziwy sens miłości do swoich współbraci: jest gotów oddać za nich życie, jak uczynił to już wcześnie sam Chrystus Pan, który: „stał się posłusznym aż do śmierci, a była to śmierć na krzyżu" (Flp 2,8). 


\section{Wnioski teologiczne}

Jeśli tekst Flp 3 zawiera pouczenie św. Paweła w kwestiach eschatologicznych, to wynikają one z doktryny soteriologicznej Apostoła. Dla Pawła Jezus Chrystus, jedyny Pan i Zbawiciel, przybędzie pewnego dnia, aby zbawić tych, którzy do Niego należą (Flp 3,20). Podobnie jak 1 Tes 4-5, także i ten fragment ukazuje koncepcję, którą można nazwać ,już” i ,jeszcze nie” całego życia chrześcijańskiego. Jeśli w życiu teraźniejszym dzielimy z Chrystusem jego uniżenie i cierpienia, to $\mathrm{w}$ przyszłości będziemy uczestnikami jego wywyższenia i chwały. A zatem wszystko to, co zostało zapowiedziane w sposób pośredni w tekście całego rozdziału Flp 3, dopiero w zakończeniu otrzymuje formę bezpośrednią: zbawienie jest dla św. Pawła rzeczywistością fizyczną i konkretną. W chwili paruzji „Chrystus przekształci nasze poniżone ciała na kształt swojego uwielbionego ciała” $(3,21)$. Tą wypowiedzią św. Paweł podejmuje ważny temat sygnalizowany już na zakończenie sekcji narratio: „...teraz Chrystus zostanie uwielbiony w moim ciele, czy to przez życie, czy to przez śmierć" $(1,20)$. A zatem tak dla Apostoła, jak i dla adresatów listu uwielbienie ludzkiego ciała już się rozpoczęło w Chrystusie, lecz swoje całkowite wypełnienie znajdzie dopiero w dniu zmartwychwstania umarłych. Paweł ilustruje w swoim piśmie tajemniczy proces, którego nawet śmierć nie jest w stanie powstrzymać. Bóg, który aktem wielkiej miłości, stworzył ludzkie ciało (Rdz 2,7), w chwili zmartwychwstania swojego syna, wykupi je ostatecznie z mocy złego. Fizyczny aspekt misterium zbawienia stawia nas zatem przed tajemnicą ludzkiej cielesności: jak żyć chrześcijańskim powołaniem, aby w chwili śmierci Chrystus był uwielbiony w naszym ciele. Pomocne w tym względzie jest właściwe zrozumienie Pawłowej etyki i antropologii.

Lektura szczegółowa tekstu Flp 3,1-4,1 wskazała na szczególną rolę czasownika $\sigma \tau \eta ́ \kappa \epsilon \tau \epsilon ~(4,1)$. Jest termin specyficzny dla dialektu koine, utworzony

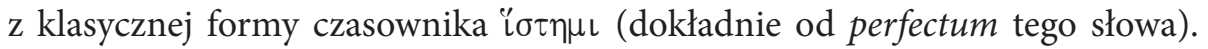

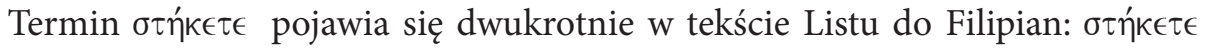

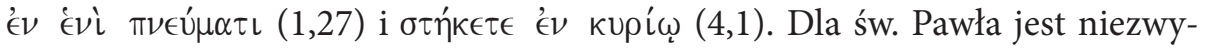
kle ważny fakt, aby Filipianie stali trzeźwo i mocno wobec spotykających ich przeciwieństw, cierpień i prześladowań, płynących ze strony świata. Czasownik

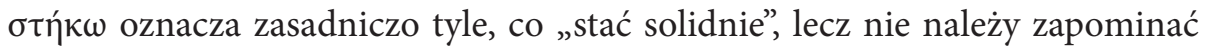
o jego najbardziej literackim znaczeniu, które wskazuje po prostu na solidną

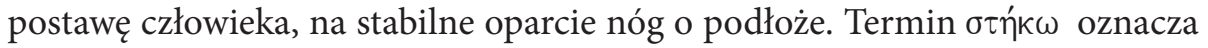
zatem tyle, co „stać mocno na nogach”. Być może wydaje się to prawdą zbyt oczywistą, a wręcz banalną, ale każdy człowiek uzależniony jest od mocy swoich nóg. Na ile jego nogi są wyćwiczone i silne, na tyle solidnie porusza się całe ciało człowieka. 
Pierwsza cześć naszej analizy egzegetycznej $(3,1-7)$ wskazywała na fałszywe pokładanie nadziei w ciele. Z kolei czwarta cześć $(3,17-4,1)$ jest emfazą podkreślającą ufność Apostoła w ostateczne przekształcenie naszego ciała. Obydwa teksty wskazują na głębokie zainteresowanie św. Pawła kwestią ludzkiego ciała i jego losu po śmierci. Tak więc Pawłowa egzorta o tym, by stać solidnie na nogach, jest przede wszystkim paraenesis Apostoła, która dotyczy ciała: jak Epafrodyt, towarzysz w pracy i wysiłkach $(2,25)$, tak Filipianie i wszyscy chrześcijanie powinni stać mocno na ziemi, aby móc kroczyć po sprawiedliwej drodze Ewangelii Chrystusa. Życie moralne chrześcijanina wymaga stałej walki przeciwko wrogom wiary w Jezusa Chrystusa. Ta batalia realizuje się tu na ziemi za pomocą ludzkiego ciała. Nie ma więc przesady w stwierdzeniu, które łączy antropologię teologiczną św. Pawła (w tym, co odnosi się do ludzkiego ciała) $\mathrm{z}$ jego teologią moralną. Jego etyka jest w rzeczywistości etyką ciała (tzw. body-ethics) ${ }^{33}$. Dzieje się tak dlatego, że w ciele ludzkim niejako krzyżują się ze sobą dwa wymiary: boski i ludzki. Ten temat stoi w centrum tajemnicy wcielenia Syna Bożego, który posiadając tę samą naturę co Bóg-Ojciec, przyjął na siebie także ludzkie ciało ze wszystkimi jego słabościami. Ta tajemnica realizuje się także we wszystkich wierzących w Chrystusa (nie zapominając o różnicach jakie istnieją pomiędzy wcielonym Synem Bożym a grzesznikami), którzy dzięki usprawiedliwieniu zdobytemu przez Jezusa Chrystusa i objawionej na drodze wiary przez działanie Ducha św. Podsumowując: ciało ludzkie jest świątynią Ducha Świętego (por. 1 Kor 6,19-20). Mimo iż słabe i grzeszne nasze ciało, jak mówi o nim św. Paweł, „upadłe” $(3,21)$ jest uświęcone przez tajemniczą obecność Ducha. A zatem życie moralne chrześcijan byłoby niemożliwe bez obecności w nim trzeciej osoby Trójcy Świętej.

Św. Paweł nie jest jednak pierwszym biblijnym autorem, który odkrył związek pomiędzy darem Ducha św. a powołaniem do prawego życia moralnego. Już ST zauważa związek pomiędzy darem Ducha i ludzką etyką ${ }^{34}$. Pawłowi zanana była owa hebrajska tradycja. Jego celem było rozwinięcie jej w świetle nauki, którą objawił Jezus Chrystus. W 1Kor 6,11 Paweł opisuje, w jaki sposób chrześcijanie zostali wyzwoleni z ich grzesznej przeszłości, która była napiętnowana grzechem i wprowadzeni na nową drogę życia w Chrystusie: zostaliście obmyci, uświęceni i usprawiedliwieni w imię Pana naszego, Jezusa Chrystusa i przez Ducha Boga naszego. Tekst ten kolejny raz potwierdza ogromne zainteresowanie św. Pawła tematyką Trójcy św., podobnie jak w tekście Flp 3,3. Zatem przebaczenie, uświęcenie i usprawiedliwienie człowieka są wolą Boga, który

33 Zob. L.E. Keck, Paul and His Letters, s. 105-109.

34 Podstawowym tekstem jest fragment z Księgi Ezechiela 35,26-27. Wartościowe uwagi podaje także Księga Mądrości 1,5 i Psalm 51,12-13. 
objawia się jeden w trzech osobach. Życie moralne i etyczne chrześcijan jest więc możliwe dzięki wielkiemu zaangażowaniu w ich działanie i postepowanie samego Boga. Dzięki darom Ducha św. otrzymanym na chrzcie św. jest rzeczywiście możliwe, dla uczniów Chrystusa, unikanie zła i czynienie dobra.

Można zatem przyjąć, że prawdziwa кoเ $\nu \omega \nu i \alpha$, o której tak wiele $w$ analizowanym liście mówi św. Paweł, wyraża się przede wszystkim w Jezusie Chrystusie, jedynym Synu Bożym, którego obecność w Kościele wyraża stała asystencja Ducha św. Moralne życie chrześcijan jest więc imitacją życia Jezusa Chrystusa, która umożliwia im łaska Bożego Ducha.

Na zakończenie wypada zaznaczyć, że subtelna obecność Ducha św. przenika całe pismo skierowane przez św. Pawła do gminy w Filippi (1.19.27; 2,1; $3,3 ; 4,23)$. Duch św. wspiera Pawła w więzieniu $(1,19)$ i pomaga Filipianom w chwilach prześladowań $(1,27)$. Jakkolwiek zgoda i jedność w Kościele nie są możliwe bez udziału Ducha św. Apostoł gorąco pragnie poznać duchową kondycję adresatów swego listu. Najważniejsze dla św. Pawła jest to, aby byli stali i jednomyślni w Duchu św. Tylko taka postawa umożliwi im prawdziwe naśladowanie Chrystusa, tak w jego cierpieniach, jak w jego wywyższeniu. Warto zwrócić także uwagę na soteriologię św. Pawła, która obecna jest także w jego doktrynie etycznej: wierzyć w Chrystusa jako Pana i Zbawiciela wymaga odpowiedniej postawy moralnej. Pozostając w komunii z Chrystusem, chrześcijanie ciągle są „w Nim”, tzn. w jego duchowym zasięgu, zaangażowani w bój przeciwko siłom zła na ziemi.

Można zatem powiedzieć, że finalne pouczenie Pawła w probatio $(4,1)$ przy-

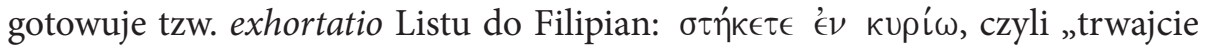
(pozostańcie) w Panu", aby służyć braciom przez Ducha św. $(3,3)$. Doskonała

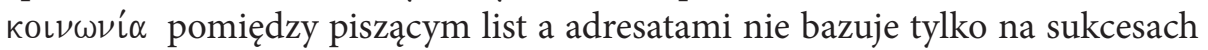
i radości, lecz wykuwa się poprzez trud ewangelizacji i służby na rzecz drugich. Naśladować Chrystusa zatem to nie wyznawać go tylko ustami (to tylko pewna cześć ciała), lecz przede wszystkim świadczyć o nim moralną postawą i działaniem, które także dokonuje się w ciele i przez ciało. Dobra nowina Listu do

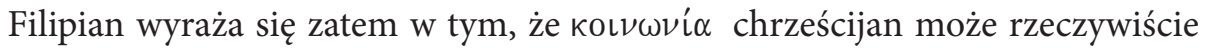
zmieniać świat poprzez działanie Ducha św., Ducha, który tworzy wspólnotę

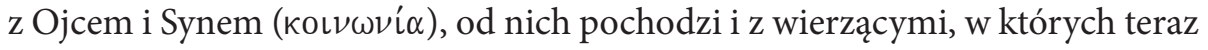
żyje. 


\section{Bibliografia}

Bloomquist L.G., The Function of Suffering in Philippians, JSNTSSup 78, Sheffield, 1993. Bormann, L., Philippi, Stadt und Christengemeinde zur Zeit des Paulus, NT.S 78, Leiden 1995.

Delling, G.D., Stoicheō, TWNT, VII, s. 666-669.

Fee G.D., Paul's Letter to the Phillippians, Grand Rapids, 1995.

Garland, D.E., The Composition and Unity of Philippians, NT 27 (1985), s. 141-173.

Gnilka J., Der Philipperbrief, HTKAT X/3; Freiburg; Basel, Wien 1968.

Grundmann W., Amemptos, TWNT, IV, s. 576-578.

Grundmann W., Symmorphizō, TWNT, VII, s. 776-798.

Jankowski A., Listy Więzienne Świętego Pawła: Do Filipian - do Kolosan - do Filemona do Efezjan, PŚNT VIII, Poznań 1962.

Keck L.E., Paul and His Letters, Philadelphia, 1988,

Lang F., Skybala, TWNT, VII, s. 446-448.

Lohfink, G., Die Himmelfahrt Jesu. Untersuchungen zu den Himmelfahrts- und Erhöhungstexten bei Lukas, SANT 26, München 1971.

Martin R.P., Hawthorne G.F., Philippians, WBC 43, Waco 1983.

Reed J.T., Philippians 3,1 and the Epistolary Hesitation Formulas: The Literary Integrity of Philippians, again. JBL 115 (1996), s. 63-90.

Schnider F., Stenger, W., Studien zum neutestamentlichen Briefformular, NTTS 11, Leiden 1987.

Theobald M., Der Philipperbrief, w: M. Ebner; S. Schreiber, Einleitung in das Neue Testament, Stuttgart 2008, s. 371-389.

Watson D.F., A Rhetorical Analysis of Philippians and Its Implications for the Unity Question, NT 30 (1988), s. 57-88.

Walter N., Die Philipper und das Leiden. Aus der Anfängen einer heidnischen Gemeinde, w: R. Schnackenburg, Die Kirche des Anfangs, FS: H. Schürmann, Freiburg in Breisgau 1978, s. 417-434.

Wilk J., Postawa świętej obojętności Apostoła Pawła na podstawie Listu do Filipian 4,11-13, w: W. Chrostowski; D. Kotecki., Scrutamini Scripturas (J 5,39). Ksiega Jubileuszowa dla Księdza Biskupa Andrzeja W. Suskiego w rocznicę 75. urodzin, Warszawa 2016, s. 467-477.

Wischmeyer O., Paulus. Leben-Umwelt-Werk-Briefe, Tübingen 2006. 